\title{
Traditional uses, Chemistry and Pharmacology of Croton species (Euphorbiaceae)
}

\author{
Antonio Salatino, * Maria L. Faria Salatino and Giuseppina Negri \\ Departamento de Botânica, Instituto de Biociências, Universidade de São Paulo, CP 11461, \\ 05422-970, São Paulo - SP, Brazil
}

Croton é um gênero de Euphorbiaceae com cerca de 1300 espécies, amplamente distribuídas em regiões tropicais do Novo e Velho Mundos. Várias espécies há muito tempo desempenham papel importante nos usos tradicionais de plantas medicinais na África, Ásia e América do Sul. Tais usos incluem tratamento de câncer, constipação intestinal, diarréia e outros problemas digestivos, diabetes, feridas externas, febre, hipercolesterolemia, hipertensão, inflamação, vermes intestinais, malária, dor, úlceras e obesidade. Várias espécies de Croton têm um látex vermelho que contém, em algumas espécies, pró-antocianidinas e/ou alcalóides. Os alcalóides de Croton são a taspina ou substâncias relacionadas a benzilisoquinolinas. Os diterpenos são muito comuns em Croton, correspondendo a clerodanos, cembranóides, halimanos, cauranos, labdanos, ésteres do forbol, traquilobanos e sarcopetalanos. Algumas espécies são aromáticas, devido à presença de óleos voláteis. Representantes de novas classes de substâncias (fenilbutanóides, alcalóides glutarimidínicos e diterpenos sarcopetalanos) têm sido isoladas de espécies de Croton. Enquanto laticíferos têm sido descritos em espécies de Croton, até o momento não há estudos anatômicos sobre estruturas secretoras de óleos voláteis. Parece haver afinidades químicas no gênero relacionadas à geografia, agrupando espécies com (i) cauranos e/ou labdanos, (ii) traquilobanos e (iii) alcalóides. Os ensaios farmacológicos freqüentemente vêm corroborando os usos tradicionais de espécies de Croton. Grande parte dos ensaios farmacológicos trata do clerodano trans-desidrocrotonina, envolvendo uma grande diversidade de efeitos, incluindo hipolipidêmico, hipoglicêmico, antiestrogênico e anticâncer. Efeitos citotóxicos também vêm sendo observados em ensaios com alcalóides (taspina) e com diterpenóides secocaurenos, labdanos e cembranóides. Vários outros efeitos de substâncias de Croton têm sido relatados, incluindo anti-hipertensivos, antiinflamatórios, antimaláricos, antimicrobianos, antiespasmódicos, antiulcerogênicos, antivirais e mio-relaxantes.

Croton is a genus of Euphorbiaceae comprising around 1,300 species, widespread in tropical regions of the Old and New Worlds. Several species have a long role in the traditional use of medicinal plants in Africa, Asia and South America. Popular uses include treatment of cancer, constipation, diabetes, digestive problems, dysentery, external wounds, fever, hypercholesterolemia, hypertension, inflammation, intestinal worms, malaria, pain, ulcers and weight-loss. Several species of Croton have a red sap, in some species containing proanthocyanidins and/or alkaloids. The latter may be taspine or some of several benzylisoquinoline-like compounds. Diterpenes are very common in Croton, corresponding to clerodanes, cembranoid, halimanes, kauranes, labdanes, phorbol esters, trachylobanes and sarcopetalanes. Some species are aromatic due to the possession of volatile oils. Representatives of new classes of compounds (phenylbutanoids, glutarimide alkaloids, sarcopetalane diterpenes) have been isolated from Croton species. While laticifers have been described in Croton species, so far there are no anatomical studies about secretory structures of volatile oil. Few studies about flavonoids have been carried out with Croton species. Chemical affinities are apparent in the genus, grouping species with (i) kauranes and/or labdanes, (ii) trachylobanes and (iii) alkaloids. Pharmacological assays have frequently corroborated the traditional uses of Croton species. A great part of pharmacological assays with Croton substances dealt with the clerodane trans-dehydrocrotonin, a wide diversity of effects having been noticed, including hypolipidemic, hypoglycaemic, antioestrogen and anti-cancer. Cytotoxic effects also have been observed in assays with alkaloids (taspine) and with secokaurene, labdane and cembranoid diterpenes. Several other effects of Croton substances have been registered, including anti-hypertensive, anti-inflammatory, antimalarial, antimicrobial, antispasmodic, antiulcer, antiviral and myorelaxant.

Keywords: Euphorbiaceae, Croton, diterpenes, alkaloids, flavonoids, volatile oils, antiulcer, antitumoral, antimicrobial

\footnotetext{
*e-mail: asalatin@ib.usp.br
} 


\section{Introduction}

The World Health Organization estimates that around $80 \%$ of the world population in developing countries relies on traditional plant medicines for primary healthcare needs, of which a major proportion corresponds to plant extracts or their active principles. ${ }^{1}$

Many Euphorbiaceae are well known in different parts of the world as toxic and/or medicinal. The high diversity of the described effects is a reflex of the high chemical diversity of this plant group. Croton is a large genus of Euphorbiaceae, comprising around 1,300 species of trees, shrubs and herbs distributed in tropical and subtropical regions of both hemispheres. In the state of Rio de Janeiro alone 39 species have been identified and some have been used in popular medicine for many applications, including cancer. ${ }^{2}$ The genus is rich in constituents with biological activities, chiefly diterpenoids such as phorbol esters, clerodane, labdane, kaurane, trachylobane, pimarane etc. ${ }^{3}$ Croton is also rich in active alkaloids. ${ }^{4,5}$ Several species of the genus are aromatic, indicating the presence of volatile oil constituents. ${ }^{6,7}$ As most Euphorbiaceae, Croton species may contain latex, which is red-colored in some species, a characteristic usually associated with medicinal properties. ${ }^{8,9}$

This paper gives an account of the species used in traditional medicine, their chemistry and the pharmacological activities of crude extracts and pure compounds. The data collected are based on papers published up to March 2006. The data bases assessed include Biological and Chemical Abstracts, and ISI Web of Science.

\section{Croton Species and Traditional Uses}

\subsection{South America}

Croton cajucara Benth., popularly known as "sacaca", grows in the Brazilian Amazonian region. It is a traditional medicinal plant in the region, its leaves and stem bark being used in the form of tea or pills for the treatment of diabetes, high blood cholesterol levels and gastrointestinal disturbances, ${ }^{10}$ as well as hepatic disturbances and weight loss. ${ }^{11}$

C. celtidifolius Baill., commonly known as "sanguede-adave", is a tree found in the Atlantic forest of southern Brazil, mainly in Santa Catarina. Its bark and leaf infusions have been popularly used for the treatment of inflammatory diseases, leukemia, ulcer and rheumatism. ${ }^{12}$

C. eluteria Bennett., commonly known as "cascarilla", is a tropical shrub or small tree in the West Indies and northern South America. Its bitter bark has been widely used in traditional medicine to treat various diseases, being reported to be balsamic, digestive, hypotensive, narcotic, stomachic and tonic, and used to treat bronchitis, diarrhea and dysentery. ${ }^{13}$ It has been used also against fever and malaria, and as a substitute of Cinchona and Cascara. ${ }^{13}$

Several species of Croton, such as C. lechleri, $C$. palanostigma, $C$. draconoides and $C$. urucurana, contain a red viscous sap that is obtained upon making cuts on the bark. ${ }^{14}$ The mature trees of $C$. lechleri $\mathrm{L}$. produce a blood red to yellowish-orange sap, which is highly prized for an assumed ability to speed up the healing of wounds. On account of its blood-like appearance, the latex is called in Spanish either "sangre de drago" or "sangre de grado", translated into English as "dragon's blood" and "blood of the tree", respectively. ${ }^{5}$ C. lechleri is among several species of Croton used as purgative and tonic, and has a long history of medicinal use among people of the South American rainforest. It is a small-sized, fast growing tree, widely distributed in the upper Amazonian valleys of Ecuador and Peru. Its bark, when slashed, releases the blood-red sap, highly astringent and used to treat wounds, as a haemostatic, to accelerate healing and to protect lesions from infection. It is marketed as a health product. ${ }^{15-17}$

C. malambo Karst., a small tree that grows in western Venezuela and northern Colombia, is known as palomatias and torco. An infusion of palomatias bark is used in traditional medicine for treatment of diabetes, diarrhea, rheumatism, gastric ulcer and as anti-inflammatory and analgesic. ${ }^{18}$

C. nepetaefolius Baill., popularly called "marmeleirovermelho", is an aromatic plant native to northeastern Brazil, used as a stomachic, carminative and for the treatment of intestinal colic. ${ }^{19}$ Infusions or decoctions of the bark and leaves are commonly used for their antispasmodic properties and to relieve flatulence and to increase appetite. ${ }^{20}$

C. palanostigma Klotzsch is one of the most widely used medicinal plants of the South American tropics. The red latex from the bark is used as wound-healer, ${ }^{21}$ treating gastric ulcer and intestinal inflammation. ${ }^{22}$

C. schiedeanus Schlecht. is a tree native in Colombia, being particularly widespread in the Amazonian and Cundinamarca regions, where it is known as Almizclillo. This species is among the medicinal plants used in Colombian traditional medicine for the treatment of hypertension. ${ }^{23,24}$

C. urucurana Baill. is a tree growing in Brazil from Bahia to Rio Grande do Sul and Mato Grosso States. It is one of the Croton species with bark containing red latex. C. urucurana is employed in traditional medicine due to its analgesic and anti-inflammatory effects. ${ }^{25}$ It is used also to treat wound infection, to accelerate wound-healing and to treat rheumatism, cancer ${ }^{26}$ and other illnesses. ${ }^{27}$ 
C. zehntneri Pax. et Hoffm. is an aromatic plant native in northeastern Brazil, where it is popularly called "canelade-cunhã" and used in traditional medicine mainly as sedative, appetite stimulating, antianorexigen and for the relief of gastrointestinal disturbances; its bark and leaves are used as sweeteners in foods and drinks. ${ }^{28,29}$

\subsection{North America and Central America}

C. arboreous Millsp. is native in Mexico, where it is known as "cascarillo". In Tabasco and Chiapas a beverage is prepared from the aerial parts and used as an auxiliary anti-inflammatory in respiratory ailments. ${ }^{30}$

C. californicus Müll. Arg. is a pale olive-green perennial herb growing usually in sandy areas of the Mojave Desert. ${ }^{31}$ Indians used to make a hot poultice from its powdered leaves as pain reliever for rheumatism. ${ }^{32}$

C. draco Cham. \& Schltdl. is a shrub native in Mexico and Central America. It is one of the "sangre-de-drago" plants, bearing a red sap widely used in traditional medicine, including internal use for cough, flu, diarrhea and stomach ulcers, and topically as wound healing for cuts, open sores, herpes, anti-septic after tooth extraction and for oral sores. ${ }^{33}$

\subsection{Africa}

C. macrostachys Hochst. ex Rich. is a medium-sized deciduous tree of East Africa. Its roots are used in Tanzania as antidiabetic ${ }^{34}$ and the seeds are widely used in Somalia as purgative..$^{35}$

C. zambesicus Müll. Arg. (syn. C. amabilis Müll. Arg.; C. gratissimus Burch.) is native in tropical west and central Africa and used to treat fever, dysentery and convulsions. ${ }^{36}$ The leaf decoction is used in Benin as anti-hypertensive, anti-microbial (urinary infections) and to treat malarialinked fever. ${ }^{3,37}$

\subsection{Asia}

C. kongensis Gagnep. is popularly known in Thailand as "Plao Ngeon" or "Plao Noi". It is frequently used in folk medicine for dysmenorrhoea. ${ }^{38}$

C. oblongifolius Roxb., popularly known as "chucka", is a middle-sized tree and grows in India and Thailand. The leaves are used as tonic, the flowers against flat worms, the fruits to treat dysmenorrhoea, the seeds as purgative ${ }^{39}$ the bark to treat dyspepsia and the roots to treat dysentery. ${ }^{40}$ The bark is also used to treat chronic enlargement of the liver and remittent fever. It is applied externally to the hepatic region in chronic hepatitis. ${ }^{41}$ In Thai traditional medicine $C$. oblongifolius has been used in association with $C$. sublyratus to treat gastric ulcers and gastric cancers. ${ }^{42}$

Tribal people in India used various parts of $C$. roxburghii NP Balakr. against snake poisoning and to treat infertility, fever and wounds. ${ }^{43}$

C. sublyratus Kurz is a tropical plant growing extensively in southeastern Asian countries. In Thailand, the plant is a popular medicine used as anti-helminthic ${ }^{44}$ and to treat dermatological problems. ${ }^{45}$

C. tiglium L. is an Asian shrub or tree (up to $12 \mathrm{~m}$ tall), used in Chinese medicine as laxative. ${ }^{46}$ Other traditional uses include tumors and cancerous sores (www.hort.purdue.edu/newcrop/duke). The seeds are source of a commercially available oil (croton oil), used as purgative.

C. tonkinensis Gagnep., popularly called "Kho sam Bac Bo", is a shrub native to northern Vietnam. The dried leaves are prescribed for stomach-ache and have been used in Vietnamese traditional medicine to treat burns, abscesses, impetigo, dyspepsia and gastric/duodenal ulcers. They are a component of recipes used to treat urticaria, leprosy and psoriasis. ${ }^{47}$

\section{Chemistry}

Croton chemistry is considerably diverse. Terpenoids are the predominant secondary metabolite constituents in the genus, chiefly diterpenoids, which may belong to the cembranoid, clerodane, neoclerodane, halimane, isopimarane, kaurane, secokaurane, labdane, phorbol and trachylobane skeletal types. Triterpenoids, either pentacyclic or steroidal, have frequently been reported for Croton species. Volatile oils containing mono and sesquiterpenoids, and sometimes also shikimate-derived compounds are not rare in the genus. Several species have been reported as sources of different classes of alkaloids, a fact that enhances considerably the importance of the genus from the medicinal point of view. Phenolic substances have frequently been reported, among which flavonoids, lignoids and proanthocyanidins predominate.

\subsection{Diterpenes}

Clerodane diterpenes, an extremely diverse group of terpenoids with more than 800 known compounds, ${ }^{48}$ seem to be one of the prevalent classes of terpenoids in Croton. The furane clerodanes with a lactone ring transcrotonin and trans-dehydrocrotonin (1) have been isolated from the stem bark of C. cajucara, which yielded also the nor-clerodanes cajucarin $\mathrm{A}$, cajucarin B, cajucarin- $\beta$, cajucarinolide and sacacarin. ${ }^{49,50}$ trans- 
Crotonin and trans-dehydrocrotonin ( $t$-DCTN) were obtained from the aerial parts of $C$. cajucara. $^{51}$ Other sources of furano clerodanes are the stem barks of $C$. eluteria and $C$. urucurana. The former yielded cascallin, cascarillone, cascarillins A-D, ${ }^{13}$ cascarillins E-I, cascarilladione, eluterin $\mathrm{K}$ and pseudoeluterin B. ${ }^{52}$ Fattorusso et al..$^{53}$ isolated ten new clerodanes (eluterins A-J) from C.eluteria. The stem bark of $C$. urucurana yielded sonderianin, ${ }^{27}$ 15,16-epoxy-3,13(16)-clerodatriene-2-one and 12-epi-methyl-barbascoate. ${ }^{25}$ Clerodanes were obtained from the bark of $C$. lechleri: crolechinol and crolechinic acid, ${ }^{16}$ and the lactone clerodanes korberin $\mathrm{A}$ and korberin B. ${ }^{17}$ Crolechinic acid occurs as constituent from both the bark and red sap of $C$. lechleri. ${ }^{54}$ Methyl barbascoate is a transclerodane found as major diterpene in leaves of $C$. californicus. ${ }^{55}$ From shoots of $C$. schiedeanus, Puebla et $a l .{ }^{56}$ and Guerrero et al. ${ }^{57}$ isolated cis- and transdehydrocrotonin and the new neo-clerodanes $5 \beta$ hydroxy-cis-dehydrocrotonin and (12R)-12-hydroxycascarillone. The acid fraction of shoot extracts of $C$. schiedeanus yielded two new cis-clerodanes (-)-methyl16-hydroxy-19-nor-2-oxo-cis-cleroda-3,13-dien-15,16olide-20-oate and (+)-15-methoxyfloridolide A. ${ }^{58}$ Palmeira et al. ${ }^{59}$ isolated the new clerodanes crotobrasilins $\mathrm{A}$ and $\mathrm{B}$ from leaves and stems of $C$. brasiliensis (Spreng.) Müll. Arg. The labdane crotonadiol (2) was obtained from the stem bark of $C$. zambesicus. ${ }^{60}$ From the same source, the clerodanes crotocorylifuran and crotozambefuran A-C were isolated, together with the trachylobanes $7 \beta$-acetoxytrachyloban-18-oic acid and trachyloban-7 $\beta, 18-$ diol $^{36}$ (3). Two clerodanes $3 \alpha, 4 \beta$-dihydroxy-15,16-epoxy-12oxocleroda-13(16),14-dien-9-al and 3 $\alpha, 4 \beta$-dihydroxy15,16-epoxy-12-oxocleroda-13(16)14-diene were isolated from bark of the Madagascarian $C$. hovarum Leandri. ${ }^{61}$ From leaves of plants of the same species, the clerodanes 3,12-dioxo-15,16-epoxy-cleroda13(16), 14-dien-9-al and 3 $\alpha, 4 \beta$-dihydroxy-15,16-epoxy19-nor-12-oxo-cleroda-5(10),13(16),14-triene were isolated. ${ }^{62}$ From leaves of $C$. zambesicus the trachylobane ent-trachyloban-3 $\beta$-ol was obtained. ${ }^{37}$ From the same source ent-18-hydroxy-trachyloban-3-one and the isopimarane-type diterpenoid isopimara-7,15-dien-3 $\beta$ ol were also obtained. ${ }^{3} C$. tonkinensis, a species native in Vietnam, has been a prolific source of ent-kauranetype diterpenoids. From leaves of this species ent-7 $\beta$ hydroxy-15-oxokaur-16-en-18-yl acetate ${ }^{63}$ and ent-1 $\alpha$ acetoxy-7 $\beta, 14 \alpha$-dihydroxy-kaur-16-en-15-one ${ }^{64}$ (4) were isolated. From the same source the known entkauranes ent-7 $\alpha, 14 \beta$-dihydroxykaur-16-en-15-one and ent-18-acetoxy-7 $\alpha$-hydroxykaur-16-en-5-one, plus the new compounds ent-1 $\beta$-acetoxy- $7 \alpha, 14 \beta$-dihydroxykaur-16-en-15-one and ent-18-acetoxy-7 $\alpha, 14 \beta$ dihydroxykaur-16-en-15-one were isolated, ${ }^{47}$ as well as obtained four new ent-kauranes: ent-1 $\alpha, 14 \alpha$-diacetoxy$7 \beta$-hydroxykaur-16-en-15-one, ent-1 $\alpha, 7 \beta$-diacetoxy$14 \alpha$-hydroxykaur-16-en-15-one, ent-18-acetoxy-14 $\alpha$ hydroxykaur-16-en-15-one and ent-(16S)-18-acetoxy$7 \beta$-hydroxykauran-15-one. ${ }^{65}$ Recently, Giang et al. ${ }^{66}$ obtained again from leaves of $C$. tonkinensis the six new ent-kauranes ent-7 $\beta$-acetoxy-11- $\alpha$-hydroxykaur16-en-15-one, ent-18-acetoxy-11- $\alpha$-hydroxykaur-16en-15-one, ent-11- $\alpha$-hydroxykaur-16-en-18-oic acid, ent-15- $\alpha$-18-dihydroxykaur-16-ene, ent- $\alpha$-18-diacetoxy-7- $\beta$-hydroxykaur-16-en-15-one and ent-(16S)1- $\alpha$-14- $\alpha$-diacetoxy-7- $\beta$-hydroxy-17-methoxykauran15 -one. Besides clerodane and kaurane derivatives, the leaves of $C$. sublyratus contain the acyclic diterpene alcohol plaunotol (5). Leaves of $C$. sublyratus are the main source of this compound, ${ }^{45}$ although it may be found also in the leaf chloroplasts of $C$. stellatopilosus Ohba. ${ }^{67}$ C. oblongifolius has been a prolific source of diterpenoids, including: $(i)$ the clerodane 11-dehydro (-) hardwickiic acid; ${ }^{68}$ ( $\mathrm{ii}$ ) the labdanes labda7,12(E),14-triene, labda-7,12(E),14-triene-17-al, labda7,12(E),14-triene-17-ol, labda-7,12(E),14-triene-17-oic acid; ${ }^{69}$ ( iii) the cembranoid diterpenes crotocembranoic acid and neocrotocembranal ${ }^{70}(6)$; (iv) the cytotoxic labdane diterpenoids 2-acetoxy-3-hydroxy-labda$8(17), 12(E)$-14-triene, 3-acetoxy-2-hydroxy-labda$8(17), 12(E)$-14-triene, and 2,3-dihydroxy-labda$8(17), 12(E), 14$-triene were also isolated from the stem bark of $C$. oblongifolius $;^{71}(v)$ the labdane nidorellol, the furoclerodane croblongifolin and the clerodane crovatin; ${ }^{72}$ (vi) the kaurane (-)ent-kaur-16-en-19-oic acid; ${ }^{40}$ (vii) the halimanes crotohalimaneic acid (7), crotohalimoneic acid and 12-benzoyloxycrotohalimaneic acid ${ }^{73}$ (viii) new labdane-type diterpenoids 3-oxygenated ent-manoyl oxide derivatives with a 8,13epoxytricyclic ring system and hydroxylabdandienes. ${ }^{74}$ (-)-Hardwickiic acid (8) was isolated from $C$. californicus, ${ }^{75}$ C. draco ${ }^{33}$ and $C$. aromaticus L., a species with red latex native in Sri Lanka. ${ }^{76}$ Draconine, a clerodane diterpene, was obtained from $C$. draco (Rodriguez-Hahn and co-workers, apud Hernandez and Delgado $\left.{ }^{77}\right)$. C. draco contains also 9(11)-dehydrokaurenoic acid, $(5 \mathrm{R} *, 8 \mathrm{R} *, 9 \mathrm{~S} *, 10 \mathrm{R} *)-15,16$-epoxy-12ox oc leroda-3,13 (16), 14 - triene-18-acid, $\left(2 \mathrm{~S}^{*}, 5 \mathrm{R} *, 8 \mathrm{R} *, 9 \mathrm{R}^{*}, 10 \mathrm{~S} *, 12 \mathrm{~S} *\right)$-12,20;15,16-diepoxy2-hydroxy-20-oxocleroda-3,13(16),14-triene-18-acid and the new clerodane $(5 \mathrm{R} *, 8 \mathrm{R} *, 9 \mathrm{~S} *, 10 \mathrm{R} *)-15,16$ - 
epoxy-12-oxocleroda-3,13(16),14-triene-18-acid. ${ }^{33}$ Secokauranes have been obtained from leaves of $C$. kongensis. ${ }^{38}$ Trachylobanes, such as $3 \alpha$-19-dihydroxy-

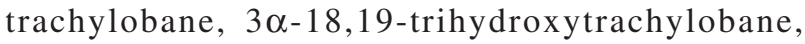
trachyloban-18-oic acid and trachylobane-19-oic acid, were obtained from roots of $C$. macrostachys, together with neoclerodan-5,10-en-19,6 $\beta, 20,12$-diolide. ${ }^{34}$ Trachyloban-19-ol and methyl trachyloban-19-oate were isolated from the stem bark of C. robustus. ${ }^{78}$ From C. zambesicus, Baccelli et al. ${ }^{79}$ isolated the novel diterpenes ent-18-hydroxytrachyloban-3 $\beta$-ol and ent18 -hydroxyisopimara-7,15-diene-3 $\beta$-ol. The pimarane diterpene 3 $\beta$-hydroxy-19- $O$-acetyl-pimara-8(9), 15 dien-7-one (9) and the labdane $2 \alpha, 3 \alpha$-dihydroxy-labda$8(17), 12(13), 14(15)$-triene were isolated from leaves of the Thailandese $C$. joufra Roxb. ${ }^{80}$ Two novel diterpenes ent-trachyloban-3-one and crotinsularin were isolated from aerial parts of the Australian $C$. insularis Baillon. ${ }^{81}$ From the same plant source, three new clerodanes were obtained, namely furocrotinsulolides
$\mathrm{A}$ and $\mathrm{B}$, and crotinsulactone. ${ }^{82}$ From shoots of $C$. salutaris Casar, a tree from southeast Brazil, Itokawa et al. ${ }^{83}$ obtained the acyclic diterpenes [(10E)-3,12dihydroxy-3,7,11,15-tetramethyl-1,10,14-hexadecatrien-5,13-dione, (6E,10E)-3,12-dihydroxy3,7,11,15-tetramethyl-1,6,10,14-hexadecatetraen-5,13dione and (6Z,10E)-3,12-dihydroxy-3,7,11,15-tetramethyl-1,6,10,14-hexadecatetraen-5,13-dione] and a tricyclic diterpene [12-hydroxy-13-methylpodocarpa9,11,13-trien-3-one], in addition to sonderianol. A prenylbisabolone diterpene with insecticidal effect was obtained from the Jamaican $C$. linearis Jacq. ${ }^{84}$ In addition to yucalexins B-6 and P-4, roots of $C$. sarcopetalus Muell., a shrub native in Bolivia and central and northwestern Argentina, contain diterpenes bearing the novel skeleton sarcopetalane: sarcopetaloic acid and two sarcopetalolides, namely sarcopetal-15en-3-one-12,13-olide (10) and sarcopetal-15-en-3 $\beta$-ol12,13-olide; the same plant source contains junceic acid and stress metabolites..$^{85,86}$<smiles>CC1=CC(=O)C[C@]23C[C@@H](c4ccoc4)OC(=O)[C@]12CCC[C@@H]3C</smiles>

1. trans-Dehydrocrotonin

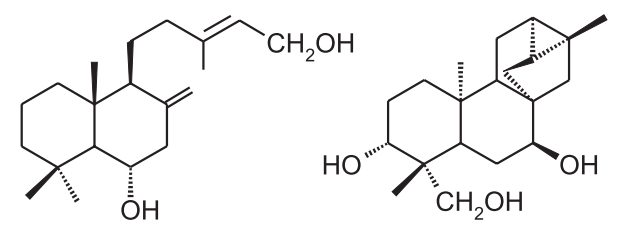

2. Crotonadiol
3. Trachyloban-7 $\beta, 18-d i o l$

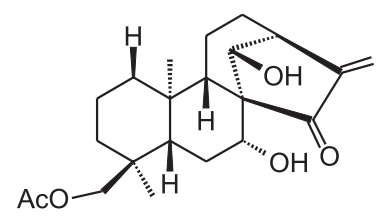<smiles>CC(C)=CCC/C(C)=C/CC/C(=C/CC/C(C)=C/CO)CO</smiles>

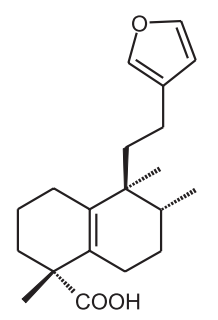

7. Crotohalimaneic acid<smiles>C[C@@H]1CC[C@H]2C(C(=O)O)=CCC[C@H]2[C@H]1CCc1ccoc1</smiles>

8. (-)-Hardwickiic acid<smiles>C=CC1(C)CCC2=C(C1)C(=O)CC1C2(C)CCC(O)C1(C)COC(C)=O</smiles>

9. 3ß-Hydroxy-19-O-acetylpimara-8(9),15-dien-7-one<smiles>CC1=CC2OC(=O)CC3C4(C)CCC(=O)C(C)(C)C4CCC23C1</smiles>

10. Sarcopetal-15-en-3-one12,13-olide 
Phorbol esters are produced by species of Euphorbiaceae and Thymelaeaceae. ${ }^{87}$ Among Croton species, only C. tiglium, native and cultivated in India, has been extensively studied as source of phorbol derivatives, having been shown to contain tigliane phorbol esters. The main irritant component of $C$. tiglium seeds is 12-O-tetradecanoylphorbol-13-acetate, a tumor promoter used in experimental mice cancer research. ${ }^{88}$ Other phorbol esters of $C$. tiglium seeds include 13-O-acetylphorbol-20linoleate, 13-O-tigloylphorbol-20-linoleate, 12-Oacetylphorbol-13-tigliate, 12-O-decanoylphorbol-13-(2methylbutyrate), 12-O-tigloylphorbol-13-(2-methylbutirate) and 12-O-acetylphorbol-13-decanoate ${ }^{89}(\mathbf{1 1}), 12-$ O-tetradecanoylphorbol-13-acetate and 12-O-(2methylbutiroyl)-phorbol-13-dodecanoate. ${ }^{90}$ C. macrostachys also probably contains phorbols in its laxative seeds. ${ }^{35}$ Small amounts of a phorbol ester was detected in flowers of C. draco. $^{33}$

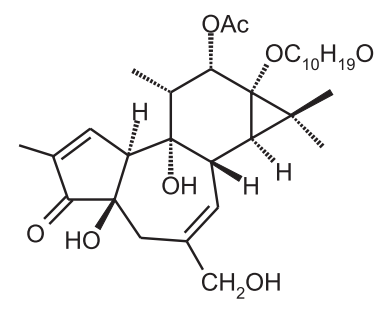

11. 12-O-Acetylphorbol-13decanoate

\subsection{Volatile oils and their constituents}

Although most Euphorbiaceae are plants not known as aromatic, some Croton species contain volatile oils. Other species have not been reported as bearing volatile oils, although they were shown to possess sesquiterpenes commonly found in volatile oils. The volatile oils of several species contain phenylpropanoids and terpenoids (mono and sesquiterpenes), while from other species only terpenoids have been obtained.

The volatile oils of leaves and stem bark of $C$. nepetaefolius belong to the first above category. It contains monoterpenes (such as 1,8-cineole) and terpineol, sesquiterpenes (such as bicyclogermacrene), and volatile phenylpropanoids (such as methyleugenol) and the acetophenone xanthoxylin. ${ }^{91}$ The volatile oil from shoots of $C$. zehntneri seems to be composed mainly of phenylpropanoids, such as anethole, methyleugenol and estragole. ${ }^{6,92}$ Methyleugenol is also found with terpenoids in volatile oils of other Croton species, such as the Central American C. jimenezii Standl. \& Valerio. ${ }^{93}$ A volatile oil was obtained from the roots of $C$. sarcopetalus, with trans- methylisoeugenol as main constituent. ${ }^{86}$ The volatile oil of the aerial parts of the Venezuelan C. malambo is composed mainly of methyleugenol, methylisoeugenol, elemicine, isoelemicine veratral and $\delta$-cadinol. ${ }^{94}$ The volatile oil of the shoots of $C$. cuneatus Miq., another Venezuelan species, comprise $\alpha$-11-eudesmene, methyleugenol, methylisoeugenol, 4- $\alpha$-seleniol, cedryl-propyl ether, $\tau$-cadinol, cubenol, veratral and agarospirol. ${ }^{94}$ The same plant source yielded the sesquiterpene sellin-11-en4o-ol.

From the second category belongs the volatile oil of $C$. cajucara, which is believed to contain sesquiterpenes, ${ }^{95}$ although it is known to be rich in the monoterpene linalool. ${ }^{96-98}$ Linalool and cineol are monoterpenoids seemingly relatively frequent in Croton. Both are relevant constituents of the volatile oil of the African C. oligandrum Pierre ex Hutch. ${ }^{99}$ Linalool is among the major constituents of the volatile oil of C. stellulifer Hutch., an endemic species of $\mathrm{S}$. Tomé and Príncipe; this oil contains kessane, a sesquiterpenoid oxide not found elsewhere in Croton. ${ }^{100}$ The volatile oil of leaves of $C$. sacaquinha Benth. also contains linalool, in addition to the sesquiterpenes $\beta$-elemene and germacrene D. ${ }^{7} 1,8$-Cineol is an important constituent of the oil of $C$. sonderianus Müll. Arg. ${ }^{101}$ Murillo et al. ${ }^{33}$ obtained the nor-terpenoids 9-dehydrovomifoliol and 2,3-dihydrovomifoliol from seeds and 1-hydroxyjunenol from the bark of C. draco. The sesquiterpenes $\tau$-cadinol and epicubenol and the acetophenone xanthoxylin were found in shoots of $C$. hieronymi Griseb. ${ }^{102}$ The sesquiterpenes caryophyllene oxide and trans-caryophyllene were found to predominate in leaves, while caryophyllene oxide and cubenol predominate in stems of $C$. sellowii Baill., a species from northeast Brazil. In the roots of the same species, mesitylene and the sesquiterpenes $\alpha, \beta$ and $\gamma$-eudesmol were the main compounds. ${ }^{103}$ Shoots of C. arboreus Millsp., an arboreous species from Mexico, contain the sesquiterpenes $5 \alpha, 7 \alpha, 10 \beta \mathrm{H}-3$-patchoulen2-one, $5 \alpha, 7 \alpha, 10 \beta \mathrm{H}-4$-(14)- patchoulen- $2 \alpha$-ol and $9 \alpha, 10 \beta$-dihydroxy-2 $\beta, 4 \beta$-peroxy- $1 \alpha, 5 \beta, 7 \alpha \mathrm{H}$-guaiane, along with 14 other known compounds, including the clerodane junceic acid. ${ }^{30}$ Another species with volatile oil containing predominantly sesquiterpenes (caryophyllene, caryophyllene oxide, germacrenes, cadinol, spathulenol) is the Venezuelan $C$. ovalifolius Vahl. ${ }^{104}$ Leaves of $C$. zambesicus have volatile oil containing mostly sesquiterpenes ( $\beta$-caryophyllene, caryophyllene oxide and $\alpha$-copaene), monoterpenes (linalool and $\beta$-pinene) and smaller amounts of diterpenes (trachylobanes, isopimaranes and kaurenes). ${ }^{105}$ 


\subsection{Pentacyclic triterpenoids and steroids}

The aerial parts of $C$. draco contain $\beta$-sitosterol, stigmasterol and the new sterol ergasterol-5 $\alpha-8 \alpha$ endoperoxide. ${ }^{77}$ From leaves of $C$. betulaster Müell. Arg., a species from northeast Brazil, Barbosa et al. ${ }^{106}$ obtained the triterpenes lupenone, lupeol, 3-oxo-22-hydroxyhopane, 3-oxo-20- $\beta$-hydroxytaraxastane, 3-oxo-20hydroxylupane, 3-oxo-olean-12-en-28-oic acid, 3-oxoolean-18-en-28-oic acid, and 3-oxo-cycloart-24E-en-26oic acid. The triterpene acetyl aleuritolic acid (12) has been obtained from two Croton species native in Brazil, C. cajucara $^{49,50}$ and C. urucurana. ${ }^{27,107}$ From methanol extracts of the latter species, stigmasterol, $\beta$-sitosterol, campesterol and $\beta$-sitosterol- $O$-glucoside were obtained. Shoots of $C$. hieronymi contain a C-25 analog of transphytol and triterpenes, such as $\alpha$ - and $\beta$-amyrin, lupeol and hop-22(29)-en-3 $\beta$-ol, in addition to the squalene derivatives all-trans-10-methylene-2,6,10,14,18,22hexaen-3-ol and 2,6,15,19,23-pentamethyltetracosa$2,6,10(28), 14,22,28$-hexaene-11-ol, and steroids, such as cholesterol, cholest-8(14)-en-3 $\beta$-ol, stigmasterol, gramisterol, sitosterol, campesterol, 22-dihydrobrassicasterol, lophenol (13), isofucosterol, stigmasterol, cholest-4-en-3-one, ergosta-4-22-dien-3-one and sitostenone. ${ }^{102}$

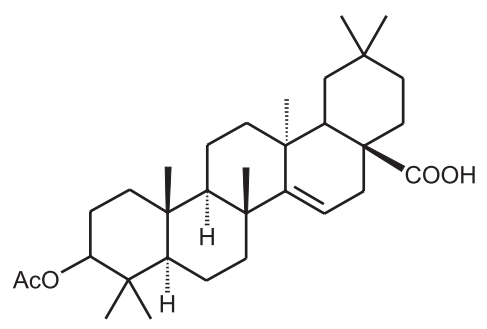

12. Acetyl aleuritolic acid

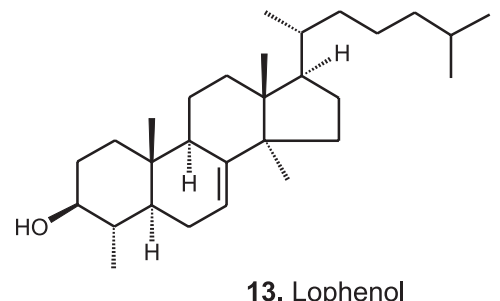

\subsection{Alkaloids}

Alkaloids are not common in Euphorbiaceae, but some Croton species are notable for their alkaloids. The most frequent Croton alkaloids are compounds identical or similar to substances found in Ranunculales, i.e. alkaloids biogenetically related to benzylisoquinolines, such as morphinandienones and tetrahydroprotoberberine alkaloids. Glutarimide alkaloids and a new class of sesquiterpene guaiane-type alkaloids have recently been obtained from Croton species.

Taspine (14), an unusual alkaloid with a dilactone structure resembling elagic acid and one nitrogen atom not included in a heterocyclic ring, was found in the red latex of three species, C. draco,$^{33,108}$ C. lechleri ${ }^{9,109}$ and $C$. palanostigma. ${ }^{110}$ Taspine has been obtained also from plant sources of benzylisoquinolines and biogenetically related alkaloids, such as Berberidaceae and Magnoliaceae. From leaves of $C$. lechleri other alkaloids, probably related biogenetically to taspine, have also been isolated, such as glaucine (15), isoboldine, magnoflorine, norisoboldine, thaliporphine ${ }^{5}$ and sinoacutine. ${ }^{11}$ Tetrahydroprotoberberine alkaloids have been reported for $C$. hemiargyreus Müll. Arg. and C. flavens L. From leaves and stems of the former Amaral and Barnes ${ }^{4}$ isolated 2,10-dihydroxy-3,10dimethoxy-8 $\beta$-methyldibenzo[a,g]-quinolizidine (hemiargyrine) (16), in addition to glaucine, oxoglaucine, salutaridine (17) and norsalutaridine. The tetrahydroprotoberberine alkaloids scoulerine and coreximine and the morphinanedienone alkaloids salutaridine and salutarine, in addition to sebiferine, norsinoacutine and flavinantine, were isolated from specimens from Barbados of $C$. flavens by Eisenreich et al. ${ }^{112}$ From leaves of $C$. flavens, Charris et al. ${ }^{113}$ isolated (-)-amuronine. From shoots of $C$. salutaris Barnes and Soeiro ${ }^{114}$ isolated salutarine and salutaridine, the latter a biosynthetically precursor of morphine. ${ }^{15}$ Isoboldine and laudanine were found in the ethanolic extracts of leaves and twigs from C. celtidifolius. ${ }^{116}$ Stuart and Graham ${ }^{117}$ verified that $C$. linearis synthesizes crotonosine through linearisine. Murillo et al. ${ }^{33}$ obtained two known aporphines from the bark and wood of $C$. draco. The $\beta$-carboline alkaloids 2ethoxycarbonyltetrahydroharman and 6-hydroxy-2methyltetradydroharman (18) were obtained from plants of $C$. moritibensis Bail., a species from northeastern Brazil. ${ }^{118}$ The aerial parts of $C$. cuneatus yielded the new glutarimide alkaloids julocrotol, isojulocrotol and julocrotone (19), in addition to julocrotonine. ${ }^{119}$ Anabasine and the novel guaiane-type alkaloids muscicapines A, B and $C$ (20) were isolated from roots of the Northeastern Brazilian C. muscicapa Müll. Arg. ${ }^{120}$

\subsection{Proanthocyanidins}

Tannins are polyphenols virtually ubiquitous in plants. They are medicinally important if occurring in high proportions in the plants. They may be formed by the combination of catechin monomers (the so-called 
<smiles>COc1ccc2c(=O)oc3c(OC)cc(CCN(C)C)c4c(=O)oc1c2c34</smiles>

14. Taspine<smiles>COc1cc2c(cc1OC)-c1c(OC)c(OC)cc3c1[C@@H](C2)N(C)CC3</smiles>

15. Glaucine<smiles>COc1cc2c(cc1O)[C@H]1Cc3cc(O)c(OC)cc3C(C)N1CC2</smiles>

16. Hemiargyrine<smiles>COC1=CC23CCC(CN2C)C2=CC(=O)C(OC)=CC23CC1</smiles>

17. Salutaridine<smiles>CC1c2[nH]c3ccc(O)cc3c2CCN1C</smiles>

18. 6-Hydroxy-2-methyltetrahydroharman

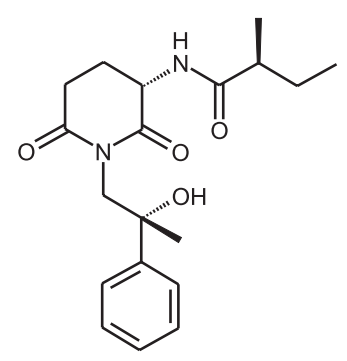

19. Julocrotone

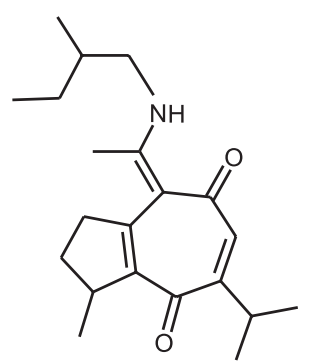

20. Muscicapin C proanthocyanidins), or by ester bounded units of glucose, gallic and/or ellagic acid (hydrolysable tannins). So far, only proanthocyanidins have been characterized in Croton species.

Proanthocyanidins have been reported as important active principles of sangre de drago species, i.e. species containing red latex. ${ }^{121}$ In such species, proanthocyanidins with several degrees of polymerisation and molecular size comprise almost $90 \%$ of the red latex dry weight. $C$. urucurana also contains proanthocyanidins and catechins in its red latex. ${ }^{122}$ A specific proanthocyanidin coded SP303 , with average molecular weight of 2,100 daltons, ${ }^{123}$ was isolated from the red latex of C. lechleri. ${ }^{124}$ Tannins seem to be important active principles also of $C$. zambesicus. ${ }^{125}$ Cai et al. ${ }^{15}$ detected proanthocyanidins as major constituents, accounting for up to $90 \%$ of the dry weight of $C$. lechleri red latex. Monomers such as (+)catechin, (-)-epicatechin, (+)-gallocatechin, (-)epigallocatechin and dimeric procyanidins B-1 and B-4 were isolated. Dimers and trimers were also obtained and characterized as catechin-(4- $\alpha \rightarrow 8)$-epigallocatechin, gallocatechin-(4- $\alpha \rightarrow 8)$-epicatechin, gallocatechin-(4$\alpha \rightarrow 6)$-epigallocatechin, catechin-(4- $\alpha \rightarrow 8)$-gallocatechin-
(4- $\alpha \rightarrow 8)$-gallocatechin and gallocatechin-(4- $\alpha \rightarrow 8)$ gallocatechin-(4- $\alpha \rightarrow 8)$-epigallocatechin. Similar tannic compounds were obtained from the red latex of $C$. panamensis (Klotzsch) Müll. Arg. ${ }^{126}$ Dalbo et al. ${ }^{127}$ detected in a fraction of the crude extract of $C$. celtidifolius bark polymeric and dimeric proanthocyanidins, the latter represented mainly by catechin- $(4-\alpha \rightarrow 8)$-catechin and gallocatechin- $(4-\alpha \rightarrow 8)$-catechin.

\subsection{Flavonoids and other phenolic substances}

Flavonols and/or flavones are ubiquitous in vascular plants, at least in green tissues. From the red latex of $C$. draco $^{108}$ and C. panamensis ${ }^{126}$ myricitrin (myricetin-3$O$-rhamnoside) was isolated. Leaves of $C$. cajucara yielded kaempferol-3,7-dimethyl ether and 3,4',7trimethyl ether, ${ }^{50}$ while shoots of $C$. schiedeanus contain quercetin-3,7-dimethyl ether. ${ }^{24}$ From leaves of $C$. betulaster Müll. Arg., Barbosa et al. ${ }^{106}$ obtained 5hydroxy,7,4'-dimethoxyflavone, and from leaves of $C$. hovarum Leandri, Krebs and Ramiarantsoa ${ }^{62}$ isolated the flavone $C$-glycoside vitexin (21). From leaves and stems of C. brasiliensis, Palmeira et al. ${ }^{59}$ isolated the 3- 
<smiles>O=c1cc(-c2ccc(O)cc2)oc2c(C3(O)OC(CO)C(O)C(O)C3O)c(O)cc(O)c12</smiles>

21. Vitexin (Agenin-8-C-glucoside)<smiles>COc1ccc(-c2oc3cc(OC)c(OC)c(O)c3c(=O)c2OC)cc1OC</smiles>

22. Artemetin<smiles>COc1ccc([C@H]2Oc3c(OC)cc(CCCO)cc3C2CO)cc1OC</smiles>

24. 3',4-O-Dimethylcedrusin

23. 3'-(4"-Hydroxy, 3",5"-dimethoxyphenyl)propyl benzoate

methoxyflavones artemetin (22), casticin, chrysosplenol$\mathrm{D}$ and penduletin. The $n$-hexane extract of the Caribbean and Central American C. ciliatoglanduliferus Ort. yielded the highly methoxylated flavonols retusin and pachypodol. ${ }^{128}$ Flavonoid data is still too scarce to establish a pattern for Croton. The available data suggest a common presence of flavonols and flavones as free highly methoxylated aglycones. It is important to note, however, that no investigation directed specifically to flavonoids, which is currently made in hydro-alcoholic extracts, ${ }^{129}$ has been carried out with Croton species. Hence, it is quite possible that flavonol and/or flavone glycosides (present in green tissues of most angiosperm species), have not been detected in the so far reported Croton chemical analyses.

Only recently were phenyl propanoids reported for the first time in Croton. From the aerial parts of $C$. hutchinsonianus Hos., a species native in Thailand, two new compounds were isolated, namely 3'-(4"'-hydroxyphenyl)-propyl benzoate and 3'-(4"'-hydroxy-3",5"dimethoxyphenyl)-propyl benzoate (23), together with the known 3'-(4"-hydroxy-3"-methoxyphenyl)-propyl benzoate. ${ }^{130}$

Lignoids are common in plant groups bearing benzylisoquinolines and related alkaloids (derived biosynthetically from tirosine), such as Ranunculales and Magnoliales. As was commented above, some Croton species possess this class of alkaloids. However, only one lignoid has so far been found in Croton, the dihydrobenzofuran lignan $3^{\prime}, 4-O$-dimethylcedrusin (24). It is interesting to note that this lignan co-occur with taspine, having been found in C. lechleri ${ }^{9}$ and C. palanostigma,${ }^{131}$ both species with red latex.

\subsection{Other classes of compounds}

Scopoletin (a coumarin) was obtained from the wood extract of $C$. draco; the seeds of the same species contain $p$-hydroxybenzaldehyde and $p$-methoxybenzoic acid, while the dried sap yielded 3,4,5-trimethoxycinnamic alcohol. ${ }^{33}$ Phenylbutanoids, an interesting class of compounds known to occur in some genera of angiosperms, were obtained from shoots of $C$. schiedeanus by Puebla et al. ${ }^{132}$ These authors isolated (2S)-7,9-dimethoxyrhododendrol (25), (2S)-acetoxy-7,9-dimethoxyrhododendrol and (2S)-2,8diacetoxy-7,9-dimethoxyrhododendrol. The formation of this class of phenolics has been proposed to occur via decarboxylative condensation of 4-coumaroil-CoA with malonyl-CoA to produce $\mathrm{C}_{6} \mathrm{C}_{4}$ skeletons. ${ }^{133}$ The novel compounds 4-(2-hydroxyethyl)-benzoic acid and 2,5dihydroxy-phenylethanol were isolated from the red sap of C. panamensis. ${ }^{126}$ Lichexanthone was obtained from the aerial parts of $C$. cuneatus. ${ }^{119}$ From the same source, Hernandez and Delgado ${ }^{77}$ obtained a mixture of polyprenols, castaprenol-11 being the major compound. Using hightemperature high resolution gas chromatography coupled to mass spectrometry (HT-HRGC-MS), Pereira et al., ${ }^{2,134}$ characterized in shoots of $C$. hemiargyreus more than 100 compounds, including alkaloids, amino acids, terpenoids and wax esters. Among the compounds detected is a high molecular mass triterpenoid (simiarenol) and esters of amyrine with fatty acids containing carbon chains above 20 atoms. The polyalcohols 1L-1-O-myo-inositol and neoinositol were isolated from shoots of C. celtidifolius. ${ }^{135}$ Benzoyl-methylpolyols were isolated from $C$. betulaster and Croton luetzelburgii Pax \& K. Hoffm. ${ }^{136}$ Furanoarabinogalactan, a polysaccharide, is the main component found 
in the gum exsudate from $C$. urucurana. ${ }^{137}$ The peptide derivatives aurentiamide acetate and $N$-benzoylphenylalanine were isolated from shoots of $C$. hieronymi. ${ }^{102}$ Cyclopeptides were reported for the red latex of C. draco. ${ }^{108}$<smiles>COc1cc(CC[C@H](C)O)cc(OC)c1O</smiles>

25. 7,9-Dimethoxyrhododendrol

\section{Chemotaxonomy}

Given the huge dimension of the genus and the so far minute sampling of species chemically studied, no definite conclusions can be drawn about chemical relationships among Croton species. However, the present picture of the distribution of compound classes is suggestive of chemical patterns in the genus (Figure 1) and encourages proposals of chemical affinities, which in turn may stimulate further work on prospects of Croton biologically active compounds.
The most common class of compounds of Croton is represented by diterpenoids. Apparently, clerodane is the widest spread class of diterpenoids in Croton, which has been found in species from America (e.g. C. cajucara), Africa (e.g. C. macrostachys) and Asia (e.g. C. oblongifolius). Phorbol esters (such as 11) seem also to be widespread in Croton, having been found in species from Asia (e.g. C. tiglium), Africa (e.g. C. macrostachys) and America (e.g. C. californicus). Thus, the common possession of clerodanes and phorbol esters by groups of species should be viewed as retention of an ancient characteristic, rather than a mark of natural affinity.

Instead, kauranes, labdanes and trachylobanes seem to be more restricted in their distribution. C. draco, $C$. kongensis, $C$. sublyratus and $C$. tonkinensis are chemically akin due to the possession of kauranes. Labdanes occur in C. joufra, C. oblongifolius and C. zambesicus. Trachylobanes have been found in $C$. insularis, $C$. macrostachys, $C$. robustus and $C$. zambesicus. It is worth noting that, with the exception of $C$. draco (a species with a highly diverse chemistry), all other species with these diterpene classes do not occur in the New World, most of them occurring in Asia, C. zambesicus in Africa and $C$.

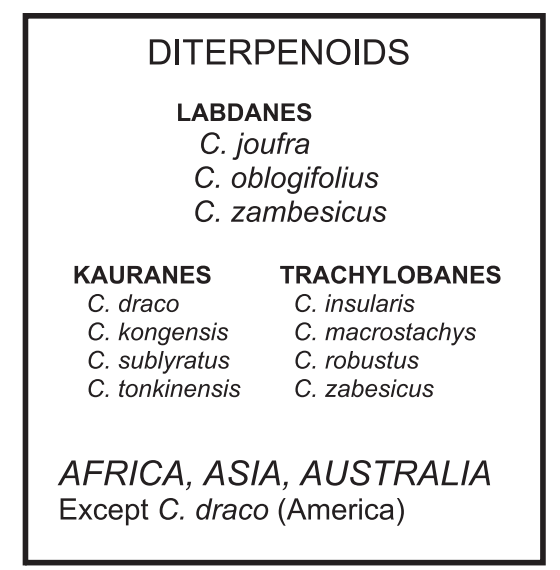

\begin{tabular}{|c|c|}
\hline \multicolumn{2}{|c|}{$\begin{array}{c}\text { TASPINE AND/OR } \\
\text { BENZYLISOQUINOLINE-LIKE } \\
\text { ALKALOIDS }\end{array}$} \\
\hline \multicolumn{2}{|l|}{ C. celtidifolius } \\
\hline C. draco & $\begin{array}{l}\text { 3',4-DIMETHYL- } \\
\text { CEDRUSIN }\end{array}$ \\
\hline C. flavens & C. lechleri \\
\hline C. hemyargyreus & C. palanostigma \\
\hline C. linearis & \\
\hline C. salutaris & \\
\hline \multicolumn{2}{|c|}{ AMERICA } \\
\hline
\end{tabular}

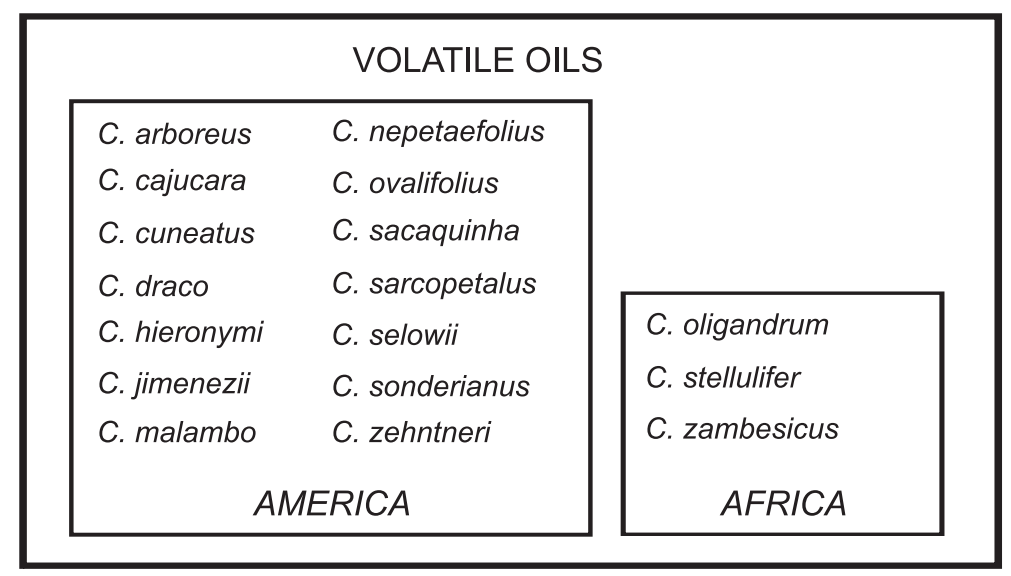

Figure 1. Chemical and geographical affinities among Croton species. 
insularis in Australia (Figure 1). A recent molecular phylogeny of Croton has been published, ${ }^{138}$ but unfortunately few chemically studied species were included. Nonetheless, it is interesting that $C$. kongensis and C. zambesicus are grouped in a same clade. Other classes of diterpenoids, such as cembranoid, pimarane and isopimarane diterpenes seem to be highly restricted. In Croton, cembranoids have been found only in C. oblongifolius, which so far is the sole known halimane diterpenoid bearer. In Croton, isopimaranes are so far exclusive of $C$. zambesicus and pimaranes of $C$. joufra (Figure 1). Up until now, $C$. sarcopetalus is the sole known source of sarcopetalane diterpenoids.

Assuming the possession of diterpenes as an ancient chemical feature in Croton, the apparent absence of diterpenoids in extant Croton species indicates that the ability to produce or accumulate such compounds was lost in the evolutionary process. It has been claimed that terpenoid production by plants is more costly than other secondary metabolites. ${ }^{139}$ It seems that loss of diterpenoids in Croton occurred during the spread of Croton species into America. Benzylisoquinoline-like alkaloids (15-17) are an important group of secondary metabolites found so far exclusively in American Croton species, namely $C$. celtidifolius, C. draco, C. flavens, C. hemiargyreus, $C$. lechleri, C. linearis, C. palanostigma and C. salutaris (Figure 1). Again, it is worth noting that $C$. lechleri and $C$. flavens emerge inside a same clade in Croton molecular phylogeny. ${ }^{138}$ Alkaloids from other classes also occur in American Croton species, such as glutarimide alkaloids in C. cuneatus (Venezuela), $\beta$-carbolines in $C$. moritibensis (Brazil) and anabasine and guaiane-type alkaloids in $C$. muscicapa (Brazil). There seems to be in Croton a nearly mutual exclusiveness between diterpenes and alkaloids. Among the mentioned alkaloid-bearer species only $C$. salutaris has been reported to bear alkaloids and diterpenoids. C. lechleri and C. palanostigma are akin also due to the common possession of taspine (14), high amounts of proanthocyanidins and the lignoid 3',4-dimethylcedrusin (24) (Figure 1). As commented above, lignans are common in plant groups that produce benzylisoquinolines. In addition, these two species, plus $C$. celtidifolius, have red latex. Red sap occurs also in non-alkaloidal species, such as $C$. cajucara and $C$. urucurana, which share the possession of the rare triterpenoid acetyl aleuritolic acid (12).

Another trend that possibly occurred in the chemical evolution of Croton is the loss of diterpenoids and the substitution by mono and sesquiterpenes, mainly as volatile oil constituents, accompanied sometimes by shikimate derived volatiles (e.g. methyl eugenol, and anethole). Volatile oils have been reported from $C$. arboreous, $C$. cajucara, $C$. cuneatus, C. draco, C. hieronymi, C. jimenezii, C. malambo, C. nepetaefolius, C. oligandrum, C. ovalifolius, C. sacaquinha, C. sarcopetalus, $C$. selowii, $C$. sonderianus, $C$. stellulifer, C. zambesicus and C. zentneri (Figure 1). Among these species only $C$. arboreous, $C$. cajucara, C. draco, $C$. sarcopetalus and $C$. zambesicus have been reported to possess diterpenoids and volatile oils. Volatile oils seem to be absent from alkaloidal species; so far only $C$. cuneatus was shown to bear both volatile oil and alkaloids, the latter represented by the rare glutarimide-type alkaloids. Most aromatic species occur in America, the exceptions being C. oligandrum (Africa), C. stellulifer (S. Tomé and Príncipe, Gulf of Guinea, west of Africa) and C. zambesicus (Africa).

A molecular phylogeny of Croton, including plants with known chemistry, would be extremely helpful to clarify trends in the chemical evolution of the genus.

\section{Pharmacological Effects of Plant Parts and Crude Extracts}

\subsection{Antilipidemic}

Extracts of $C$. cajucara leaves showed significant reductions in the serum total cholesterol, low-density lipoprotein cholesterol and triglyceride levels, as well as a significant elevation in the HDL/total cholesterol ratio in treated rats compared with the control group. ${ }^{140}$ Experiments treating rats with water extracts ${ }^{11}$ gave support to the popular use of $C$. cajucara bark in loss-weight programs. Treated rats had lower weight gain than control rats, the sensitivity of the lipolytic responses to isoprenaline and adrenaline being significant higher in adipocytes from treated rats.

\subsection{Wound healing, gastric effects and protection}

Extracts of the bitter bark of cascarilla (C. eluteria) has been shown to strengthen the histamine-stimulated gastric acid secretion, giving experimental support to the use of cascarilla in bitter preparations aimed to improve digestion. ${ }^{141}$ The "sangre de grado" of $C$. lechleri has shown wound-healing activity ${ }^{142}$ in cutaneous disorders and, orally, in a dilute form to facilitate the healing of gastric ulcers, reducing ulcer size and bacterial content of the ulcer. ${ }^{143}$

The volatile oil from the bark of $C$. cajucara has been shown to exert gastric ulcer healing activity, as well as protection of the gastric mucosa. ${ }^{144}$ Low molecular weight sesquiterpenes appear to be important active constituents of the volatile oil. ${ }^{95}$ Efficacy of the oil seems to be based on its ability to stimulate local mucus synthesis and prostaglandin production by the gastric mucosa. ${ }^{145}$ 


\subsection{Anti-diarrheic}

The red sap from $C$. urucurana showed promising potential for the control of pathologies associated with secretory diarrhea. ${ }^{122}$ Proanthocyanidin SP-303 (from sangre de drago of $C$. lechleri) is a potent inhibitor of cholera toxin-induced fluid accumulation and chloride secretion. ${ }^{146}$

\subsection{Immunomodulatory, antibacterial, antifungal and antiviral}

The red latex of $C$. lechleri showed antioxidant or prooxidant properties and stimulated or inhibited the phagocytosis. In addition, sangre de drago has immunomodulatory activity, inhibiting the proliferation of activated T-cells. ${ }^{9}$ The latex is also known to have antioxidant, free radical scavenging ${ }^{147}$ and antiviral activities. ${ }^{124}$ In addition, it has revealed anti-bacterial properties. ${ }^{142}$ The red latex from C. urucurana inhibited the growth of the fungi Tricophyton tonsurans, Tricophyton mentagrophytes, Tricophyton rubrum, Microsporum canis and Epidermophyton floccossum, showing a potential utility as an alternative treatment for dermatophytosis. ${ }^{148}$ Phytochemical analyses demonstrated in the product the presence of catechins, such as gallocatechin and epigallocatechin, substances previously known to exert antifungal activity. The red latex of $C$. draco and its ethyl acetate and ethyl ether extracts exhibited high inhibition on the classical activation pathway of the complement system using hemolytic assay. ${ }^{108}$

\subsection{Antimalarial}

Several Croton species are traditionally used as antimalarials throughout endemic malarial areas. Antiplasmodial activity was demonstrated in vitro for C. pseudopulchellus Pax., a species from southern Africa. ${ }^{149}$ Shoot methanolic extracts from aerial parts of C. lobatus L. (a widespread species in tropical America, from Florida to Argentina) were active toward Plasmodium falciparum 3D7 chloroquine sensitive strains, while root methanolic extracts inhibited growth of $\mathrm{K} 1$ resistant strains. ${ }^{150}$

\subsection{Anticancer}

Shoots of $C$. hieronymi have shown strong activity against lung A-549 carcinoma cells and mouse lymphoma and some activity against human colon carcinoma. ${ }^{102}$ The dichloromethane extract of leaves of $C$. zambesicus showed in vitro cytotoxicity against human cervix carcinoma cells. ${ }^{37}$ The red latex of $C$. lechleri has been shown to have anti-tumor activity. ${ }^{142}$

\subsection{Antimutagenic}

C. lechleri sap possess antimutagenic properties and may inhibit the proliferation of human leukemic cells. ${ }^{151}$

\subsection{Mutagenic}

The red sap of $C$. lechleri showed mutagenic activity for strain TA1535 of Salmonella typhimurium, in the presence of metabolic activation, and weak mutagenic activity for strain TA98; mutagenic activity was also noted in the haploid Saccharomyces cerevisiae strain XV185-14c. ${ }^{152}$ Methanolic extracts of $C$. cajucara bark were tested in mice for mutagenicity and antimutagenicity. ${ }^{153}$ No statistical significant results were obtained, indicating that, at the concentrations tested, the extracts have no mutagenic effect.

\subsection{Antioxidant}

C. celtidifolius bark has anti-inflammatory and antioxidant activity, which results from the direct action of constituents on specific targets, such as cyclooxygenase. ${ }^{12}$ C. urucurana red latex has antioxidant effect against lipid peroxidation and free radical scavenging activity. ${ }^{26} C$. lechleri sap possesses significant antioxidant activity against the oxidative damages induced by apomorphine and hydrogen peroxide in Saccharomyces cerevisiae and maize plantlets. ${ }^{152}$ Leaf extracts of $C$. cajucara were observed to exert antioxidant effects against the free radical DPPH and in paraquat treated yeast cells. ${ }^{154}$

\subsection{Myorelaxant, antispasmodic and anti-hypertensive}

The volatile oil of the bark and leaves of $C$. nepetaefolius, which contains mainly 1,8-cineole, methyleugenol and terpineol, exerted antispasmodic effect on gastrointestinal tissues and antihypertensive activity in the cardiovascular system. ${ }^{155}$ Intravenous treatment with the volatile oil decreases mean aortic pressure and heart rate in either anaesthetized or nonanaesthetized rats. ${ }^{156}$ The myorelaxant activity is coherent with the use of $C$. nepetaefolius in traditional medicine as antispasmodic. Its large efficacy as a myorelaxant agent associated with its low acute toxicity makes it an agent of therapeutic potential. ${ }^{91}$ Aqueous and ethanolic extracts of $C$. schiedeanus have a decreasing effect on blood pressure, probably by means of an antihypertensive rather than hypotensive effect. ${ }^{23,157}$ The antihypertensive activity and vasodilatory effects of $C$. schiedeanus are attributed to a 
synergistic activity among flavonoids and terpenoids. ${ }^{24}$ The volatile oil of $C$. zehntneri has relaxing effect on smooth muscle, which supports the use of $C$. zehntneri in traditional medicine as a gastrointestinal antispasmodic, an activity that may in part be attributed to estragole. ${ }^{28,29}$

\subsection{Anti-inflammatory and antinociceptive}

Crude leaf extracts of $C$. cajucara exhibited significant antinociceptive effect in rats. ${ }^{10}$ The red latex of $C$. lechleri revealed strong anti-inflammatory activity. Although taspine is probably an important and active constituent of the red latex, it cannot be considered the main responsible for these activities, and other constituents, probably proanthocyanidins, should be also involved. ${ }^{9}$ Orally administered, the volatile oil of $C$. nepetaefolius promoted a dose-dependent antinociceptive effect in hot-plate test. ${ }^{158}$ The aqueous extract of the aerial parts of $C$. cuneatus had significant activity against plantar inflammation induced by bovine serum albumin. ${ }^{134}$ The volatile oil of $C$. sonderianus had antinociceptive effect in tests with oral administration, but was inactive in hot-plate tests. ${ }^{160}$ An antinociceptive effect of the volatile oil of $C$. zehntneri was evidenced, most likely associated with antiinflammatory activity. ${ }^{6}$ The aqueous extract of C. malambo bark administered intraperitoneally showed antinociceptive and anti-inflammatory effects, comparable to acetylsalicylic acid and sodium diclofenac. ${ }^{161} C$. celtidifolius bark has anti-inflammatory activity. ${ }^{12}$

\subsection{Central depressive}

The volatile oil from the bark and leaves of $C$. zehntneri produced central depressive effects in rats without anxiety alterations. ${ }^{162}$

\subsection{Reliever of insect bites swelling}

The red latex of C. lechleri relieves swelling of insect bites. $^{143}$

\section{Pharmacological Effects of Pure Compounds}

\subsection{Anti-diabetic, anti-hyperlipidemic, anti-hyper- cholesterolemic}

Pharmacological studies carried out with the terpenoids $t$-DCTN (1), trans-crotonin, acetyl aleuritolic acid (12) and with plant extracts showed a striking correlation with the traditional therapeutic use of $C$. cajucara species in the Amazon region for the control of hyperlipidemy and associated pathologies. ${ }^{50,163}$ Hypolipidemic effects were observed by in assays with $t$-DCTN from C. cajucara. ${ }^{164,165}$ In addition to hypolipidemic action, $t$-DCTN exhibited hypoglycemic effect in alloxan-induced diabetic, but not in normal rats. ${ }^{140}$

\subsection{Tumor promotion}

Phorbol esters (such as 11) are known co-carcinogenic agents, being involved in the transformation of normal human epithelial cells through infection by Epstein-Barr virus. ${ }^{166}$ The commercially available oil of Croton derives from the Asiatic C. tiglium. This oil is the source of phorbol esters, tetracyclic diterpenes isolated from the seeds, whose cocarcinogenic properties have been the object of numerous investigations. Although they have been consumed medicinally for two millennia, ${ }^{167}$ these natural products are the most powerful tumor promoters known. ${ }^{168-170}$ C. tiglium is still utilized in homoeopathy and in combination with some sort of acupuncture (as a constituent of Baunscheidt oil). Its main irritant component, 12-O-tetradecanoylphorbol-13acetate (TPA) was used as a standard tumor promoter in mice in experimental cancer research, ${ }^{88}$ but Castagna et al. ${ }^{171}$ and Nishizuka ${ }^{172}$ noted that phorbol-12-myristate-13-acetate is also effective. In addition, the latter compound is hardly metabolized by the cell. ${ }^{173}$ Several phorbol esters were prepared with polar functional groups terminating their $\mathrm{C} 12$ and/or C13 acyl chains. Such phorbol ester lipophilic domain is thought to be responsible for redistributing a phorbolprotein complex to the plasma membrane. ${ }^{174}$ Biotransformation of phorbol esters by intestinal bacteria has been successfully achieved. ${ }^{175}$

\subsection{Anticancer}

$t$-DCTN (1) exhibits anti-tumor efficacy and immunomodulatory actions in vivo, which may be related to its chemical structure. ${ }^{176}$ DCTN and its synthetic derivative dimethylamide-crotonin (DCR) inhibit HL60 cells growth in vitro partly by apoptosis induction and cell differentiation, but do not cause serious damage to immune cells. ${ }^{177,178}$ However, $t$-DCTN is not cytotoxic (and also not genotoxic) to bone marrow cells of Swiss mice submitted to acute intraperitoneal treatment in vivo ${ }^{179}$ and antimutagenic with regard to cyclophosphamide, in particular if administered by gavage. ${ }^{180}$ Correa et al. ${ }^{181}$ developed a $\beta$-cyclodextrin complex to improve delivery of DCTN. A lower cytotoxicity of the complex $\beta$-cyclodextrin-DCTN to V79 fibroblasts and rat cultured hepatocytes, compared to free $t$-DCTN, suggests that such 
complex may be useful for in vivo dehydrocrotonin administration.

The furoclerodane croblongifolin from $C$. oblongifolius showed significant cytotoxicity against BT474, CHAGO, HEP-G2, KATO3 and SW620 tumor cell lines. ${ }^{72}$ Among Croton diterpenes, not only clerodanes have been found to exert anticancer activity. Non-specific, moderate cytotoxicity agains human breast ductal carcinoma (BT474), human undifferentiated lung carcinoma (CHAGO), human liver hepatoblastoma (HEP-G2), gastric carcinoma (KATO3) and colon adenocarcinoma (SW620) tumor cell lines were shown by the following labdanes from $C$. oblongifolius: labda7,12(E),14-triene-17-al; 17-hydroxy-labda-7,12(E),14-triene; 17-acetoxylabda-7,12(E),14-triene; 15-hydroxylabda7,13(E)-diene-17,12-olide; labda-7,13(E)-diene-17,12-olide and 12,17-dihydroxylabda-7,13(E)-diene. ${ }^{39}$ The labdanes from C. oblongifolius 2,3-dihydroxy-labda-8(17),12(E),14triene showed non-specific, moderate, cytotoxicities against all the cell lines BT474, CHAGO, HEP-G2, KATO3 and SW620, whereas 2-acetoxy-3-hydroxy-labda-8(17),12(E),14triene and 3-acetoxy-2-hydroxy-labda-8(17),12(E),14-triene were less active, because their ability to form hydrogen bond with certain receptors in tumor cells made them more selective but less active. ${ }^{71}$ Also halimane and cembranoid diterpenes from $C$. oblongifolius showed antitumoral activity, but 12-benzoyloxycrotohalimaneic acid was inactive. ${ }^{73}$ Neocrotocembranal (6) inhibited platelet aggregation induced by thrombin and exhibited cytotoxicity against P-338 cells in vitro. ${ }^{70}$ ent-Kauranes of $C$. tonkinensis also have been shown to be cytotoxic. ${ }^{66}$ Block et al. ${ }^{37}$ reported for the first time cytotoxic activity of a trachylobane (ent-trachyloban$3 \beta$-ol), a constituent of leaves of $C$. zambesicus. The same compound has recently been shown to induce apoptosis in human promyelocytic leukemia cells in a concentrationdependent manner. ${ }^{182}$

Phorbol esters may exert potent co-carcinogenic activity but, among them, many exert beneficial biological effects without tumor promotion, such as prostratin. ${ }^{183}$ Actually, some naturally occurring phorbol esters are tumor inhibitors. ${ }^{90} 12-O$-Tigloylphorbol-13-decanoate has been shown to have activity against the P 388 lymphocytic leukemia in mice. ${ }^{184}$

Plaunotol (5), an acyclic diterpene present in C. sublyratus leaves, has recently been shown to have anti-cancer activity through inhibition of angiogenesis. ${ }^{185}$ Anethole, a phenylpropanoid constituent of $C$. zehntneri volatile oil, has been shown to have anti-carcinogenic effect. ${ }^{186}$

Taspine (14) is active against KB and V-79 cells, a fact that makes it a likely responsible for the purported anticancer activity of $C$. lechleri red sap. ${ }^{142}$ Positive results in antitumor tests using breast carcinoma and hepatoma cells were obtained with the glutarimide alkaloids julocrotol, isojulocrotol and julocrotone (19) isolated from the aerial parts of $C$. cuneatus. ${ }^{119}$

\subsection{Antibacterial, antifungal and antiviral}

8,9-Secokauranes from C. kongensis exhibited antimycobacterial activity at the minimum inhibitory concentration of 6.25-25.0 $\mu \mathrm{g} \mathrm{mL} \mathrm{m}^{-1}{ }^{38}$ Plaunotol (5) has exhibited activity against twenty methicillin-resistant and fourteen methicillin-sensitive strains of Staphylococcus aureus. ${ }^{187,188}$ The results suggested that plaunotol might be useful in the prevention of infection and skin care for patients with atopic dermatitis.

Tannins are known to complex with proteins, acting as multidentate ligands and thus being able to bind simultaneously to more than one point to the protein surface. ${ }^{189}$ Proanthocyanidin SP-303 has been extensively studied and has shown activity against a variety of virus: respiratory syncytial virus, parainfluenza type-1 and type3 , and influenza A and B viruses; ${ }^{190}$ herpes virus; ${ }^{191}$ genital and anogenital herpes virus, in treatment of patients with AIDS; ${ }^{192}$ several DNA and RNA virus, including hepatitis viruses. ${ }^{143} C$. tiglium seeds contain anti-HIV-1 phorbol esters, 12-O-acetylphorbol-13-decanoate (11) and 12-Odecadienoylphorbol-13-(2-methylbutyrate) that inhibit the cytopathic effect of HIV-1; 12-O-tetradecanoylphorbol13-acetate (TPA) is even more active than the mentioned phorbol esters against HIV-1. ${ }^{89,90}$

Catechin and acetyl aleuritolic acids, compounds obtained from $C$. urucurana, are effective against $S$. aureus and Salmonella typhimurium; acetyl aleuritolic acid showed minimum inhibitory concentration ten fold higher than catechin. ${ }^{27}$ Alviano et al. ${ }^{98}$ observed that the volatile oil from leaves of $C$. cajucara, composed mostly by linalool, inhibits the growth of Candida albicans, Lactobacilus casei, Porphyromonas gengivalis, S. aureus and Streptococcus mutans, all involved in diseases of the oral cavity. Among these microorganisms, the authors noted that linalool is active almost exclusively against Candida albicans, and that the volatile oil is not toxic to mammalian cells.

The phenylpropyl benzoates 3'-(4"-hydroxy-3",5"dimethoxyphenyl)-propyl benzoate, 3'-(4"-hydroxyphenyl)propyl benzoate and 3'-(4"-hydroxy-3"-methoxyphenyl)-propyl benzoate, obtained from stems of $C$. hutchinsonianus, were shown to exert effect against Candida albicans. ${ }^{130}$

Derivatives of phorbol esters have been evaluated as inhibitors of proliferation of HIV-1. Among them 12-Oacetylphorbol-13-decanoate has been shown to be the most potent. ${ }^{193,194}$ 


\subsection{Wound-healing, gastric effects and protection}

$t$-DCTN (1) showed strong antiulcerogenic activity. ${ }^{195,196}$ The A-ring of both crotonin and DCTN is not directly involved in the antiulcerogenic activity. ${ }^{197} t$-DCTN has good antiulcerogenic activity; a long term use of which, however, may induce liver damage. ${ }^{198}$ A semi-synthetic crotonin, namely 4SRC, was synthesized and it was shown to have a significant preventive effect against gastric ulcer induced by different agents. ${ }^{199}$ Presence of a lactone moiety or Michael acceptor is probably essential for the antiulcerogenic effect, a mechanism of gastric cytoprotection being mediated by an action on prostaglandin biosynthesis, and by a Michael reaction between the SH-containing compounds of the mucosa on the Michael acceptors present in antiulcerogenic compounds. ${ }^{200}$

When previously administered orally the volatile oil from the bark of Croton cajucara significantly reduced the gastric injury induced in rats. ${ }^{95,144}$

Plaunotol is an anti-peptic ulcer agent, ${ }^{201}$ commercially available under the name Kelnac. ${ }^{45}$ The anti-ulcer effect of plaunotol is probably linked to its activity against Helicobacter pilory. ${ }^{202,203}$

\subsection{Antispasmodic and anti-diarrheic}

The volatile oils of some South-American Croton species are antispasmodic. Cineole, methyleugenol and terpineol, constituents of $C$. nepetaefolius volatile oil, have been reported to have myorelaxant and antispasmodic effects in laboratory animals. ${ }^{153}$ Experimental results suggest that $C$. nepetaefolius volatile oil induces relaxation of guinea-pig ileum. ${ }^{204}$ Anethole and estragole, major components of the volatile oil of $C$. zehntneri, are effective relaxants of skeletal muscles. ${ }^{205}$

Fischer et al. ${ }^{147}$ described a method to optimize the preparation of an extract from the bark latex of $C$. lechleri. The extract was named SB-300 and contains on average $70.6 \%$ by weight of the proanthocyanidin SP-303. The authors suggest its use for the treatment of fluid loss in acute watery diarrhea. SP-303 is the active agent of Provir, a $C$. lechleri derived product with antisecretory properties ${ }^{206,207}$ and hence useful to control fluid loss and diarrhea. SP-303 has been indicated particularly for patients of AIDS, common victims of diarrhea. ${ }^{208}$

\subsection{Anti-inflammatory and antinociceptive}

From the aerial parts of $C$. arboreous, AguilarGuadarrama and Rios ${ }^{30}$ obtained four sesquiterpenes with anti-inflammatory activity against ear edema in mice. The active sesquiterpenes are $5 \alpha, 10 \beta-4(15)$-eudesmen-1 $\beta, 6 \beta$ diol, spathulenol, $5 \alpha, 10 \beta$-3-eudesmen-1 $\beta, 6 \alpha$-diol and the diterpenoid junceic acid.

The volatile oil of $C$. zehntneri was shown to have antinociceptive activity in mice, ${ }^{6}$ and the volatile oil of C. cajucara has anti-inflammatory and antinociceptive effects in rodents. ${ }^{209}$ Cajucarinolide, a diterpene from $C$. cajucara, was shown to possess anti-inflammatory activity and to inhibit bee venom phospholipase A2 in vitro. ${ }^{210}$ DCTN, the main component of bark extracts of $C$. cajucara, has anti-inflammatory and analgesic effects. ${ }^{50,211}$

A chromatographic analysis from the ethyl acetate soluble fraction of the crude extract of the stem bark of C. celtidifolius showed predominantly proanthocyanidins, which exhibited antinociceptive effects in tests using intraperitonial injections of chemical stimulants. ${ }^{127}$

\subsection{Vasorelaxant, hypotensive and bradycardiac}

$t$-DCTN (1) was shown to reduce the mean arterial pressure and heart rate in a dose-dependent manner in normotensive rats and to relax the tonic contraction in isolated rat aortic rings induced by phenylephrine. ${ }^{212}$ The neo-clerodanes (12R)-12-hydroxycascarillone, 5 $\beta$ hydroxy-cis-dehydrocrotonin, cis- and trans-dehydrocrotonin from $C$. schiedeanus relaxed aort rings. ${ }^{57} \mathrm{~A}$ cooperactivity between diterpenoids and quercetin-3,7dimethyl ether (ayanin, the predominant flavonoid in $C$. schiedeanus leaves) was observed in the relaxing effect. Flavonoids have been assigned a role as protectors against vascular accidents. A vasorelaxant activity of quercetin3,7-dimethyl ether from C. schiedeanus was observed, the activity probably being influenced by hydroxylation at positions 3' and 4' of the B ring. ${ }^{24}$

\subsection{Central anti-depressive}

While the volatile oil of $C$. zehntneri exhibited depressive effects in models using rats (see above), methyleugenol, its major constituent, was shown to have antidepressive effect in experiments based on the same models. ${ }^{213}$

\subsection{Anti-oestrogenic}

$t$-DCTN (1) obtained from C. cajucara was tested for anti-oestrogenic activity using immature rats for bioassay of oestrogen and regularly cycling rats of proven fertility for antiimplantation effect. The compound prevented increases of uterine wet weights, but did not affect blastocyst implantation. ${ }^{214}$ 


\subsection{Insect growth inhibition and insecticidal}

The diterpene fraction from $C$. linearis showed lethal effect on insects. ${ }^{84}$ A prenylbisabolane diterpene from $C$. linearis has insecticidal effect. ${ }^{215}$ The same comment applies to hardwickiic acid, a diterpene present in $C$. aromaticus and C. californicus. ${ }^{76}$

\subsection{Anti-leishmanial and anti-malarial activity}

The linalool-rich volatile oil from leaves of C. cajucara was shown to be a potent agent against Leishmania amazonensis. The $\mathrm{DL}_{50}$ for promastigotes is $8.3 \mathrm{ng} \mathrm{mL}^{-1}$

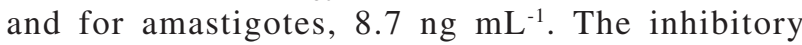
concentration for L. amazonensis promastigotes growth is extremely low (MIC $85.0 \mathrm{pg} \mathrm{mL}^{-1}$ ), and the oil has no cytotoxic effects against mammalian cells. ${ }^{97}$ 8,9Secokauranes obtained from $C$. kongensis were shown to have anti-malarial activity with $\mathrm{IC}_{50} 1.0-2.8 \mu \mathrm{g} \mathrm{mL}^{-1} .^{38}$

\section{Concluding Remarks: Points Deserving Further Work}

Table 1 summarizes traditional uses and effects observed in pharmacological assays with species of Croton and respective substances. Taking into account the magnitude of the genus, the list of species is still too scant. However, a quick examination of the table contents suffices to give an idea of the wide diversity of $(i)$ health problems, which people from many parts of the world treat with the aid of Croton plant parts, (ii) classes of Croton secondary metabolites, and (iii) pharmacological effects experimentally observed, using crude extracts and pure compounds. For these reasons, much chemical and pharmacological work is needed about Croton. So far only one species of Croton is known as source either of halimane and cembranoid ( $C$. zambesicus), or isopimarane ( $C$. zambesicus) or sarcopetalane ( $C$. sarcopetalus) diterpenoids. Paul Berry estimates that there are 354 known Croton species native in Brazil, one of the important hotspots of Croton diversity (www.cria.org.br/eventos/tdbi/flora/presentations/ PaulBe). Nevertheless, as yet Croton literature reports results of chemical and/or pharmacological research related with only the following Brazilian species: $C$. betulaster, C. brasiliensis, C. cajucara, C. celtidifolius, C. eluteria, C. lobatus, C. luetzelburgii, C. moritibensis, C. muscicapa, C. nepetaefolius, C. palanostigma, C. sacaquinha, C. salutaris, C. sellowii, C. sonderianus, C. urucurana and $C$. zehntneri. Fortunately, a rapid inventory in the ISI Web of Science reveal that approximately 30 papers have been published annually from 2000 to 2005 about Croton chemistry and/or pharmacology. It is important to note that figures much higher would emerge if articles were also counted without Croton in their titles, but dealing with chemical or pharmacological aspects of the genus. Hence, Croton species and their substances are among the highly studied themes in chemistry of natural products, pharmacology and ethnopharmacology, and new data are rapidly accumulating. It is expected that many novelties will rapidly enlarge the current knowledge about Croton species, their substances and corresponding pharmacological effects.

Some trends in Croton research should be rechecked. It is evident from the Reference list of the present work that some species have been the object of relatively many investigations, such as $C$. cajucara, C. lechleri, $C$. urucurana and $C$. zehntneri, whilst most Croton species have so far been neglected by chemists and pharmacologists.

A lot of further work is also necessary about traditional uses of Croton species, not only in Brazil, but also in other tropical regions of both New and Old Worlds. Indeed, the number of Croton species reported in the literature as sources of traditional medicines is too small, if it is considered the high diversity of Croton species, chemistry and pharmacology.

For several species in Table 1, there is good agreement between popular uses and experimentally observed effects, in harmony with Fairnsworth's observation ${ }^{216}$ that popular uses of medicinal plants frequently are coherent with the pharmacological effects of the main active principles of the respective plant sources. Part of the future pharmacological investigations should center their focus on several popular uses of Croton species, which so far have received no scientific support, as are the cases of $C$. californicus (rheumatism pain), C. draco (several traditional uses), C. eluteria (bronchitis, fever, malaria), C. kongensis (dysmenorrhoea), C. macrostachys (diabetes, purgative), C. malambo (diarrhea), $C$. oblongifolius (several traditional uses), C. palanostigma (wounds, digestive problems), C. roxburghii (infertility, fever, wounds), C. sublyratus (intestinal worms, dermatological problems), C. tonkinensis (several traditional uses), C. urucurana (pain), C zambesicus (fever, malaria, convulsions) and $C$. zehntneri (anorexia) (Table 1). On the other hand, experimental work has uncovered potential uses of Croton chemicals with no records in the list of popular uses. A few examples are the cytotoxic, antimycobacterial and 
Table 1. Species of Croton, traditional uses and pharmacological effects reported for plant parts and some important isolated compounds. Several species treated in the text are not included for lack of information of either traditional uses or pharmacological assays

\begin{tabular}{|c|c|c|}
\hline Species & Traditional uses & Effects of plant parts and relevant isolated components \\
\hline C. arboreous & Anti-inflammatory & Four sesquiterpenes $\rightarrow$ anti-inflammatory ${ }^{30}$ \\
\hline C. cajucara & $\begin{array}{l}\text { Diabetes, hypercholesterolemia, digestive } \\
\text { disturbances, hepatic disturbances, } \\
\text { weight-loss }\end{array}$ & $\begin{array}{l}\text { Bark volatile oil } \rightarrow \text { gastric ulcer healing, }{ }^{95,145} \text { anti-leishmanial; }{ }^{97} \text { bark water extract } \rightarrow \\
\text { lowering of the weight gain and higher sensitivity of adipocytes to isoprenaline } \\
\text { and adrenaline; }{ }^{11} \text { trans-crotonin, trans-dehydrocrotonin, acetyl aleuritolic acid } \rightarrow \\
\text { hypolipidemic and hypoglycaemic effects; }{ }^{50,163} \text { trans-dehydrocrotonin } \rightarrow \\
\text { anti-oestrogen, anticancer }{ }^{51} \text { linalool } \rightarrow \text { anti-bacterial and antifungal }{ }^{98}\end{array}$ \\
\hline C. celtidifolius & $\begin{array}{l}\text { Inflammation, leukaemia, } \\
\text { ulcers, rheumatism }\end{array}$ & Bark $\rightarrow$ anti-inflammatory and anti-oxidant ${ }^{12}$ \\
\hline C. eluteria & $\begin{array}{l}\text { Bronchitis, fever, malaria, digestive, } \\
\text { hipertension }\end{array}$ & Extracts of bitter bark $\rightarrow$ stimulation of gastric secretion ${ }^{141}$ \\
\hline C. kongensis & Dysmenorrhea & Secokaurane diterpenes $\rightarrow$ cytotoxic, anti-mycobacterial and anti-malarial ${ }^{38}$ \\
\hline C. lechleri & Haemostatic, wound-healing, purgative & $\begin{array}{l}\text { Red latex } \rightarrow \text { anti-inflammatory, }{ }^{9} \text { anti-viral, }{ }^{124} \text { antibacterial, }{ }^{142} \text { anti-leukemic } ;{ }^{151} \\
\text { SP-303 } \rightarrow \text { anti-viral: respiratory syncytial, },{ }^{191} \text { genital and anogenital simplex lesions, }{ }^{192}\end{array}$ \\
\hline C. macrostachys & Purgative, diabetes & Seeds and roots $\rightarrow$ purgatives $^{35}$ \\
\hline C. malambo & $\begin{array}{l}\text { Pain, rheumatism, inflammation, } \\
\text { diarrhea, diabetes, gastric ulcer }\end{array}$ & Bark extract $\rightarrow$ antinociceptive, anti-inflammatory ${ }^{161}$ \\
\hline C. nepetaefoilius & $\begin{array}{l}\text { Stomachic, flatulence, intestinal colic, } \\
\text { appetizer }\end{array}$ & $\begin{array}{l}\text { Volatile oil } \rightarrow \text { antispasmodic; }{ }^{91,155,204} \text { cineole, methyleugenol } \rightarrow \text { myorelaxant } \\
\text { and antispasmodic }{ }^{155}\end{array}$ \\
\hline C. oblongifolius & $\begin{array}{l}\text { Many applications, including liver } \\
\text { enlargement, fever and flat worms }\end{array}$ & Shoot extract $\rightarrow$ anti-hepatotoxic activity; ${ }^{41}$ diterpenes $\rightarrow$ cytotoxic $^{39,70-73}$ \\
\hline C. palanostigma & $\begin{array}{l}\text { Intestinal inflammation, wound-healing, } \\
\text { gastric ulcers }\end{array}$ & Taspine $\rightarrow$ cytotoxic $^{110,142}$ \\
\hline C. schiedeanus & Hypertension & $\begin{array}{l}\text { Aqueous and ethanolic extracts; }{ }^{23,156} \text { quercetin-3,7-dimethyl ether } \rightarrow \text { vasorelaxan } \\
\text { and anti-hypertensive }{ }^{24}\end{array}$ \\
\hline C. tonkinensis & $\begin{array}{l}\text { Stomach-ache, dyspepsia, gastric and } \\
\text { duodenal ulcers, leprosy, psoriasis, } \\
\text { urticaria }\end{array}$ & Cytotoxic diterpenes ${ }^{66}$ \\
\hline C. sublyratus & Anthelmintic and dermatologic problems & Plaunotol $\rightarrow$ anti-peptic ulcer activity, ${ }^{201-203}$ anticancer, ${ }^{185}$ anti-bacterial ${ }^{187}$ \\
\hline C. urucurana & $\begin{array}{l}\text { Pain reliever, inflammation, wound } \\
\text { infection, wound-healing, cancer }\end{array}$ & $\begin{array}{l}\text { Bark red latex } \rightarrow \text { anti-diarrheic, }{ }^{122} \text { antifungali, }{ }^{148} \text { catechin, acetyl aleuritolic } \\
\text { acid } \rightarrow \text { antibacterial; } ; 2 \text { acetyl aleuritolic acid } \rightarrow \text { analgesic }{ }^{25}\end{array}$ \\
\hline C. zambesicus & $\begin{array}{l}\text { Fever, malaria, convulsions, hypertension, } \\
\text { microbial infections, dysentery }\end{array}$ & Leaves $\rightarrow$ cytotoxicity ${ }^{37}$ trachylobane diterpene $\rightarrow$ cytotoxic $^{37}$ \\
\hline C. zehntneri & $\begin{array}{l}\text { Nervous disturbances, anorexia, } \\
\text { gastrointestinal disturbances, sweetener }\end{array}$ & $\begin{array}{l}\text { Volatile oil } \rightarrow \text { intestinal muscle relaxant, }{ }^{28,29} \text { depressor central effect, }{ }^{162} \\
\text { antinociceptive; }{ }^{6} \text { anethole and estragole } \rightarrow \text { intestinal muscle relaxant; }{ }^{28} \\
\text { anethole } \rightarrow \text { anti-carcinogenic }{ }^{186}\end{array}$ \\
\hline
\end{tabular}

antimalarial effects of secokaurane diterpenes of $C$. kongensis, the cytotoxicity of taspine, the hypolipidemic and hypoglycaemic effects of C. urucurana and the cytotoxicity of trachylobane diterpenes of $C$. zambesicus (Table 1).

Another aspect that needs investigation deals with the secretory structures involved in the production and accumulation of some Croton extractives, such as latex and volatile oils. With the exception of a study by Rudall ${ }^{217}$ about laticifer distribution in Crotonoideae and other Euphorbiaceae, nothing has been reported about structures involved in the production and accumulation of volatile oils in Croton. In angiosperms, volatile oils may be found inside oil cells (e.g. Lauraceae), secretory cavities (e.g. Myrtaceae), secretory ducts (e.g.
Asteraceae) and secretory trichomes (e.g. Lamiaceae), the latter being regarded as evolutionary more recent. ${ }^{218}$ This is certainly a point deserving research by plant anatomists.

It has been said above (see section Chemical Affinities) that, among Croton species containing alkaloids, only $C$. salutaris is known to possess also diterpenes. It was said also that most species with volatile oils have not been reported as diterpene- and alkaloid-bearers. Is this apparent mutual exclusiveness between classes of secondary metabolites a reality in Croton or just a delusion resultant of insufficient sampling? Relationships between the occurrences of classes of secondary metabolites in Croton are a point deserving consideration, because it may end up useful in future prospects of pharmacologically active substances. 


\section{Acknowledgments}

AS and MLFS are fellow researchers of $\mathrm{CNPq}$ (Conselho Nacional do Desenvolvimento Científico e Tecnológico, Brasil).

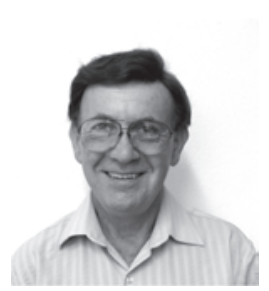

Antonio Salatino got his Ph.D. from the University of São Paulo in 1979 and carried out postdoctoral programs with Drs. Tom Mabry at the University of Texas and David E. Giannasi at the University of Georgia. He is currently Full Professor at the Department of Botany (which he headed in 2001-2004) of the Institute of Biosciences of the University of São Paulo. His research interests are chemotaxonomy and applied botany, including studies about the effects of pollution, analysis of seed oils, medicinal plants and propolis, and more recently molecular phylogeny and gene expression. Author of nearly 100 papers in national and international scientific journals.

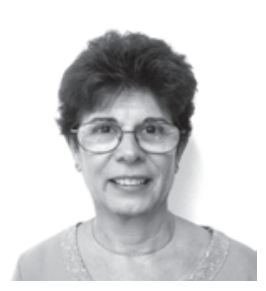

Maria Luiza Faria Salatino received her Ph.D. from the University of São Paulo and completed postdoctoral programs with Drs. Tom Mabry and David E. Giannasi. Her research deals with the analysis of plant secondary metabolites to explore their taxonomic and economic potential, and analysis of DNA with interests in molecular systematics. Presently, she is a faculty member at the Institute of Biosciences, Department of Botany and head of its Laboratory of Phytochemistry and Molecular Systematics. Author of 40 papers, including book chapters and articles of national and international scientific journals.

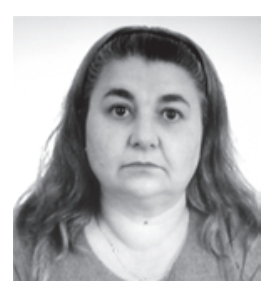

Giuseppina Negri obtained a Ph. D. in Organic Chemistry from the State University of Campinas (UNICAMP). She gained expertise in organic synthesis and mass spectroscopy working under the supervision of Prof. Dra. Concetta Kascheres. She held a post-doctorate position at the University of São Paulo, Department of Botany, when she gained familiarity with analysis of natural products. GN has carried out investigations on plant secondary metabolites, with emphasis in analysis of constituents of medicinal plants and propolis. Presently, she integrates the group led by Dr. Elisaldo Luiz de Araujo Carlini at CEBRID/UNIFESP, being involved in several projects dealing with medicinal plants with activity on the central nervous system. Author of 30 papers, including book chapters and articles of national and international scientific journals.

\section{References}

1. Sampson, J. H.; Phillipson, J. D.; Bowery, N. G.; O’Neill, M. J.; Houston, J. G.; Lewis, J. A.; Phytother. Res. 2000, 14, 24.

2. Pereira, A. S.; Carbonell, S. A.; Aquino Neto, F. R.; Fernandes D. O.; Amaral, A. C. F.; Barnes, R. A.; J. Chromatogr. A 2002, 947, 254.

3. Block, S.; Baccelli, C.; Tinant, B.; Meervelt, L. C.; Rozenberg, R.; Jiwan, J-L. H.; Llabrès, G.; Pauw-Gillet, M-C.; QuetinLeclercq, J.; Phytochemistry 2004, 65, 1165.

4. Amaral, A. C. F.; Barnes, R. A.; Phytochemistry 1998, 47, 1445.

5. Milanowski, D. J.; Winter, R. E. K..; Elvin-Lewis, M. P. F.; Lewis, W. H.; J. Nat. Prod. 2002, 65, 814.

6. Oliveira, A. C.; Leal-Cardoso, J. H.; Santos, C. F.; Morais, S. M.; Coelho-de-Souza, A. N.; Braz. J. Med. Biol. Res. 2001, 34, 1471.

7. Lopes, D.; Bizzo, H. R.; Sobrinho, A. F. S.; Pereira, M. V. G.; J. Essent. Oil Res. 2003, 15, 48.

8. Sandoval, M.; Okuhama, N. N.; Clark, M.; Angeles, F. M.; Lao, J.; Bustamante, S.; Miller, M. J.; J. Ethnopharmacol. 2002, 80, 121.

9. Risco, E.; Ghia, F.; Vila, R.; Iglesias, J.; Álvarez, E.; Canigueral, S.; Planta Med. 2003, 69, 785.

10. Campos, A. R.; Albuquerque, F. A. A.; Rao, V. S. N.; Maciel, M. A. M.; Pinto, A. C.; Fitoterapia 2002, 73, 116.

11. Grassi-Kassisse, D. M.; Wolf-Nunes, V.; Miotto, A. M.; FariasSilva, E.; Souza-Brito, A. R. M.; Nunes, D. S.; SpadariBratfisch, R. C.; J. Pharm. Pharmacol. 2003, 55, 253.

12. Nardi, G. M.; Felippi, R.; Dalbó, S.; Siqueira-Junior, J. M.; Arruda, D. C.; Delle Monache, F.; Timbola, A. K.; Pizzolatti, M. G.; Ckless, K.; Ribeiro-do-Vale, R. M.; Phytomedicine 2003, $10,176$.

13. Vigor, C.; Fabre, N.; Fourasté, I.; Moulis, C.; Phytochemistry 2001, 57, 1209.

14. Duke, J.; Vasquez, R.; Amazonian Ethnobotanical Dictionary, CRC Press: Boca Raton, 1994.

15. Cai, Y.; Evans, F.; Roberts, M.; Phillipson, J. D.; Zenk, M.; Gleba, Y.; Phytochemistry 1991, 30, 2033.

16. Cai, Y.; Chen, Z. P.; Phillipson, J. D.; Phytochemistry 1993, 32, 755.

17. Cai, Y.; Chen, Z. P.; Phillipson, J. D.; Phytochemistry 1993, 34, 265.

18. Suárez, A. I.; Compagnone, R. S.; Salazar-Bookaman, M. M.; Tillet, S.; Delle Monache, F.; Di Giulio, C.; Bruges, G.; J. Ethnopharmacol. 2003, 88, 11.

19. Moura, V. L. A.; Monte, F. J. O.; Braz-Filho, R.; J. Nat. Prod. 1990, 53, 1566.

20. Lahlou, S.; Leal-Cardoso, J. H.; Magalhães, P. J. C.; Planta Med. 2000, 66, 138.

21. Porrasreyes, R. H.; Lewis, W. H.; Roman, J.; Simchowitz, L.; Mustoe, T. A.; Proc. Soc. Exp. Biol. Med. 1993, 203, 18. 
22. Miller, M. J. S.; MacNaughton, W. K.; Zhang, X-J.; Thompson, J. H.; Charbonnet, R. M.; Bobrowski, P.; Lao, J.; Trentacosti, A. M.; Sandoval, M.; Am. J. Physiol.-Gastroint. Liver Physiol. 2000, 279, G192.

23. Guerrero, M. F.; Carrón, R.; Martin, M. L.; San Román, L.; Reguero, M. T.; J. Ethnopharmacol. 2001, 75, 33.

24. Guerrero, M. F.; Puebla, P.; Carrón, R.; Martin, M. L.; Román, L. S.; J. Pharm. Pharmacol. 2002, 54, 1373.

25. Peres, M. T. L. P.; Pizzolatti, M. G.; Yunes, R. A.; Delle Monache, F.; Phytochemistry 1998, 49, 171.

26. Orlandi-Mattos, P. E.; Geremias, R.; Cordova, C. A. S.; Creczynski-Pasa, T. B.; Rebello, J. M.; Wilhelm, D.; Martins, D. T. O.; Llesuy, S.; Pedrosa, R. C.; Free Radical Biol. Med. 2002, 33, 645.

27. Peres, M. T. L. P.; Delle Monache, F.; Bella Cruz, A.; Pizzolatti, M. G.; Yunes, R. A.; J. Ethnopharmacol. 1997, 56, 223.

28. Coelho-de-Souza, A. N.; Barata, E. L.; Magalhães, P. J. C.; Lima, C. C.; Leal-Cardoso, J. H.; Phytother. Res. 1997, 11, 299.

29. Coelho-de-Souza, A. N.; Criddle, D. N.; Leal-Cardoso, J. H.; Phytother. Res. 1998, 12, 189.

30. Aguilar-Guadarrama, A. B.; Rios, M. Y.; J. Nat. Prod. 2004, 67,914 .

31. Williams, L.; Evans, P. E.; Bowers, W. S.; J. Chem. Ecol. 2001, 27, 203.

32. Chavez, P. I.; Jolad, S. D.; Hoffmann, J. J.; Cole, J. R.; J. Nat. Prod. 1982, 45, 745.

33. Murillo, R. M.; Jakupovic, J.; Rivera, J.; Castro, V. H.; Rev. Biol. Trop. 2001, 49, 259.

34. Kapingu, M. C.; Guillaume, D.; Mbwambo, Z. H.; Moshi, M. J.; Uliso, F. C.; Mahunnah, R. L. A.; Phytochemistry 2000, 54, 767.

35. Mazzanti, G.; Bolle, P.; Martinoli, L.; Piccinelli, D.; Grgurina, I.; Animati, F.; Mugnê, Y.; J. Ethnopharmacol. 1987, 19, 213.

36. Ngadjui, B. T.; Abegaz, B. M.; Keumedjio, F.; Folefoc, G. N.; Kapche, G. W. F.; Phytochemistry 2002, 60, 345.

37. Block, S.; Stévigny, C.; De Pauw-Gillet, M. C.; De Hoffmann, E.; Llabrés, G.; Adjakidjé, V.; Quetin-Leclercq, J.; Planta Med. 2002, 68, 647 .

38. Thongtan, J.; Kittakoop, P.; Ruangrungsi, N.; Saenboonrueng, J.; Thebtaranonth, Y.; 2003. J. Nat. Prod. 2003, 66, 868.

39. Sommit, D.; Petsom, A.; Ishikawa, T.; Roengsumran, S.; Planta Med. 2003, 69, 167.

40. Ngamrojnavanich, N.; Sirimongkon, S.; Roengsumran, S.; Petsom, A.; Kamimura, H.; Planta Med. 2003, 69, 555.

41. Ahmed, B.; Alam, T.; Varshney, M.; Khan, S. A.; J. Ethnopharmacol. 2002, 79, 313.

42. Singh, M.; Pal, M.; Sharma, R. P.; Planta Med. 1999, 65, 2.

43. Gupta, M.; Mazumber, U. K.; Vanisi, M. L. M.; Sivakumar, T.; Kandar, C. C.; J. Ethnopharmacol. 2004, 90, 21.

44. Tansakul, P.; De-Eknamkul, W.; Phytochemistry 1998, 47, 1241.
45. Vongchareonsathit, A.; De-Eknamkul, W.; Planta Med. 1998, 64, 279.

46. Tsai, J. C.; Tsai, S. L.; Chang, W. C.; Biol. Pharm. Bull. 2004, 27,162

47. Giang, P. M.; Jin, H. Z.; Son, P. T.; Lee, J. H.; Hong, Y. S.; Lee, J. J.; J. Nat. Prod. 2003, 66, 1217.

48. Maciel, M. A. M.; Pinto, A. C.; Kaiser, C. R.; Magn. Reson. Chem. 2003, 41, 278.

49. Maciel, M. A. M.; Pinto, A. C.; Brabo, S. N.; Silva, M. N.; Phytochemistry 1998, 49, 823.

50. Maciel, M. A. M.; Pinto, A. C.; Arruda, A. C.; Pamplona, S. G. S. R.; Vanderlinde, F. A.; Lapa, A. J.; Echevarria, A.; Grynberg, N. F.; Côlus, I. M. S.; Farias, R. A. F.; Costa, A. M. L.; Rao, V. S. N.; J. Ethnopharmacol. 2000, 70, 41.

51. Grynberg, N. F.; Echevarria, A.; Lima, J. E.; Pamplona, S. S. R.; Pinto, A. C.; Maciel, M. A. M.; Planta Med. 1999, 65, 687.

52. Vigor, C.; Fabre, N.; Fourasté, I.; Moulis, C.; J. Nat. Prod. 2002, 65, 1180.

53. Fattorusso, E.; Tagliatela-Scafati, O.; Campagnuolo, C.; Santelia, F. U.; Appendino, G.; Spagliardi, P.; J. Agric. Food Chem. 2002, 50, 5131.

54. Costa, M.; Perles, E. C.; Fujiwara, F. Y.; Imamura, P. M.; Phytochemistry 2000, 53, 851.

55. Wilson, S. R.; Neubert, L.; Huffman, J. C.; J. Am. Chem. Soc. 1976, 98, 3669.

56. Puebla, P.; López, J. L.; Guerrero, M.; Carrón, R.; Martín, M. L.; San Román, L.; San Feliciano, A.; Phytochemistry 2003, $62,551$.

57. Guerrero, M. F.; Puebla, P.; Carrón, R.; Martín, M. L.; San Román, L.; J. Ethnopharmacol. 2004, 94, 185.

58. Puebla, P.; Correa, S. X.; Guerrero, M.; Carrón, R.; San Feliciano, A.; Chem. Pharm. Bull. 2005, 53, 328.

59. Palmeira, S. F.; Conserva, L. M.; Silveira, E. R.; J. Braz. Chem. Soc. 2005, 16, 1420.

60. Ngadjui, B. T.; Folefoc, G. N.; Keumedjio, F.; Dengo, E.; Sondengam, B. L.; Connolly, J. D.; Phytochemistry 1999, 51, 171.

61. Krebs, H. C.; Ramiarantsoa, H.; Phytochemistry 1996, 41, 561. 62. Krebs, H. C.; Ramiarantsoa, H.; Phytochemistry 1997, 45, 379.

63. Son, P. T.; Giang, P. M.; Taylor, W. C.; Aust. J. Chem. 2000, 53, 1003.

64. Minh, P. T. H.; Ngoc, P. H.; Quang, D. N.; Hashimoto, T.; Takaoka, S.; Asakawa, Y.; Chem. Pharm. Bull. 2003, 51, 590.

65. Giang, P. M.; Son, P. T.; Lee, J. J.; Otsuka, H.; Chem. Pharm. Bull. 2004, 52, 879.

66. Giang, P. M.; Son, P. T.; Hamada, Y.; Otsuka, H.; Chem. Pharm. Bull. 2005, 53, 296.

67. Wungsintaweekul, J.; De-Eknamkul, W.; Tetrahedron Lett. 2005, 46, 2125.

68. Aiyar, V. N.; Seshadri, T. R.; Phytochemistry 1972, 11, 1473.

69. Roengsumran, S.; Petsom, A.; Sommit, D.; Vilaivan, T.; Phytochemistry 1999, 50, 449. 
70. Roengsumran, S.; Singtothong, P.; Pudhom, K.; Ngamrojanavanich, N.; Petsom, A.; Chaichantipyuth, C.; J. Nat. Prod. 1999, 62, 1163.

71. Roengsumran, S.; Petsom, A.; Kuptiyanuwat, N.; Vilaivan, T.; Ngamrojanavanich, N.; Chaichantipyuth, C.; Puthong, S.; Phytochemistry 2001, 56, 103.

72. Roengsumran, S.; Musikul, K.; Petsom, A.; Vilaivan, T.; Sangvanich, P.; Pompakakul, S.; Puthong, S.; Chaichantipyuth, C.; Jaiboon, N.; Chaichit, N.; Planta Med. 2002, 68, 274.

73. Roengsumran, S.; Pompakakul, S.; Muangsin, N.; Sangvanich, P.; Nhujak, T.; Singtothong, P.; Chaichit, N.; Puthong, S.; Petsom, A.; Planta Med. 2004, 70, 87.

74. Chaichantipyuth, C.; Petsom, A.; Taweechotipatr, P.; Muangsin, N.; Chaichit, N.; Puthong, S.; Roengsumran, S.; Kawahata, M.; Watanabe, T.; Ishikawa, T.; Heterocycles 2005, 65, 809.

75. Luzbetak, D. J.; Torrance, S. J.; Hoffmann, J. J.; Cole, J. R.; J. Nat. Prod. 1979, 42, 315.

76. Bandara, B. M. R.; Wimalasiri, W. R.; Bandara, K. A. N. P.; Planta Med. 1987, 6, 575.

77. Hernandez, J.; Delgado, G.; Fitoterapia 1992, 63, 377.

78. Ngamrojanavanich, N.; Tonsiengsom, S.; Lertpratchya, P.; Roengsumran, S.; Puthong, S.; Petsom, A.; Arch. Pharm. Res. 2003, 26, 898 .

79. Baccelli, C.; Block, S.; Van Holle, B.; Schanck, A.; Chapon, D.; Tinant, B.; Van Meervelt, L.; Morel, N.; Quetin-Leclerog, J.; Planta Med. 2005, 71, 1036.

80. Sutthaivaiyakit, S.; Nareeboon, P.; Ruangrangsi, N.; Ruchirawat, S.; Pisutjaroenpong, S.; Mahidol, C.; Phytochemistry 2001, 56, 811.

81. Graikou, K.; Aligiannis, N.; Skaltsounis, A. L.; Chinou, L.; Michel, S.; Tillequin, F. O.; Litaudon, M.; J. Nat. Prod. 2004, 67, 685.

82. Graikou, K.; Aligiannis, N.; Chinou, L.; Skaltsounis, A. L.; Tilleguin, F. O.; Litaudon, M.; Helv. Chim. Acta 2005, 88, 2654.

83. Itokawa, H.; Ichihara, Y.; Takeya, K.; Morita, H.; Motidome, M.; Phytochemistry 1991, 30, 4071.

84. Alexander, I. C.; Pascoe, K. O.; Manchard, P.; Williams, L. A. D.; Phytochemistry 1991, 30, 1801.

85. de Heluani, C. S.; Catalan, C. A. N.; Hernandez, L. R.; Burgueno-Tapia, E.; Joseph-Nathan, P.; Magn. Reson. Chem. 1998, 36, 947.

86. de Heluani, C. S.; Catalan, C. A. N.; Hernandez, L. R.; Burgueno-Tapia, E.; Joseph-Nathan, P.; J. Nat. Prod. 2000, 63, 222.

87. Evans, F. J. In Naturally Occurring Phorbol Esters; Evans, E. J., ed., CRC Press: Boca Raton, 1986, p. 171.

88. Glaser, S.; Sorg, B.; Hecker, E. A.; Planta Med. 1988, 54, 580. 89. El-Mekkawy, S.; Meselly, M. R.; Nakamura, N.; Hattori, M.; Kawahata, T.; Otake, T.; Chem. Pharm. Bull. 1999, 47, 1346.

90. El-Mekkawy, S.; Meselly, M. R.; Nakamura, N.; Hattori, M.; Kawahata, T.; Otake, T.; Phytochemistry 2000, 53, 457.
91. Magalhães, P. J. C.; Criddle, D. N.; Tavares, R. A.; Melo, E. M.; Mota, T. L.; Leal-Cardoso, J. H.; Phytother. Res. 1998, 12, 172.

92. Batatinha, M. J. M.; Souza-Spinosa, H.; Bernardi, M. M.; J. Ethnopharmacol. 1995, 45, 53.

93. Ciccio, J.F.; Segnini, M.; J. Essent. Oil Res. 2002, 14, 357.

94. Suárez, A. I.; Vásquez, L. J.; Manzano, M. A.; Compagnone, R. S.; Flavour Fragr. J. 2005, 20, 611.

95. Hiruma-Lima, C. A.; Gracioso, J. S.; Nunes, D. S.; Souza-Brito, A. R. M.; J. Pharm. Pharmacol. 1999, 51, 341.

96. Lopes, D.; Bizzo, H. R.; Sobrinho, A. F. S.; Pereira, M. V. G.; J. Essent. Oil Res. 2000, 12, 705.

97. Rosa, M. D. S.; Mendonça, R. R.; Bizzo, H. R.; Rodrigues, I. D.; Soares, M. A.; Souto Padron, T.; Alviano, C. S.; Lopes, A. H. C. S.; Antimicrob. Agents Chemother. 2003, 47, 1895.

98. Alviano, W. S.; Mendonça, R. R.; Alviano, D. S.; Bizzo, H. R.; Souto-Padron, T.; Rodrigues, M. L.; Bolognese, A. M.; Alviano, C. S.; Souza, M. M. G.; Oral Microbiol. Immunol. 2005, 20, 101.

99. Agnaniet, H.; Akagah, A.; Mounzeo, H.; Menut, C.; Bessiere, J.M.; J. Essent. Oil Res. 2005, 17, 201.

100. Martins, A.P.; Salgueiro, L. R.; Gonçalves, M. J.; Vila, R.; Tomi, F.; Adzet, T.; da Cunha, A. P.; Canigueral, S.; Casanova, J.; Planta Med. 2000, 66, 647.

101. Dourado, R. C. M.; Silveira, E. R.; J. Essent. Oil Res. 2005, $17,36$.

102. Catalán, C. A. N.; Heluani, C. S.; Kotowicz, C.; Gedris, T. E.; Herz, W.; Phytochemistry 2003, 64, 625.

103. Palmeira, S. F.; Moura, F. D.; Alves, V. D.; De Oliveira, F. M.; Bento, E. S.; Conserva, L. M.; Andrade, E. H. D.; Flavour Fragr. J. 2004, 19, 69.

104. Meccia, G.; Rojas, L. B.; Rosquete, C.; San Feliciano, A.; Flavour Fragr. J. 2000, 15, 144.

105. Block, S.; Flamini, G.; Brkic, D.; Morelli, I.; Quetin-Leclercq, J.; Flavour Fragr. J. 2006, 21, 222.

106. Barbosa, P. R.; Fascio, M.; Martins, D.; Guedes, M. L. S.; Roque, N. F.; Biochem. Syst. Ecol. 2003, 31, 307.

107. Peres, M. T. L. P.; Delle Monache, F.; Pizzolatti, M. G.; Santos, A. R. S.; Beirith, A..; Calixto, J. B.; Yunes, R. A.; Phytother. Res. 1998, 12, 209.

108. Tsacheva, I.; Rostan, J.; Iossifova, T.; Vogler, B.; Odjakova, M.; Navas, H.; Kostova, I.; Kojoharova, M.; Kraus, W.; Z. Naturforsch., C: J. Biosci. 2004, 59C, 528.

109. Vaisberg, A. J.; Milla, M.; Planas, M. D.; Cordova, J. L.; Deagusti E. R.; Ferreyra, R.; Mustiga, M. D.; Carlin, L.; Hammond, G. B.; Planta Med. 1989, 55, 140.

110. Itokawa, H.; Ichihara, Y.; Mochizuki, M.; Enomori, T.; Morita, H.; Shirota, O.; Inamatsu, M.; Takeya, K.; Chem. Pharm. Bull. 1991, 39, 1041.

111. Carlin, L.; Vaisberg, A. J.; Hammond, G. B.; Planta Med. 1996, $62,90$.

112. Eisenreich, W. J.; Höfner, G.; Bracher, F.; Nat. Prod. Res. 2003, $17,437$. 
113. Charris, J.; Dominguez, J.; De La Rosa, C.; Caro, C.; Biochem. Syst. Ecol. 2000, 28, 795.

114. Barnes, R. A.; Soeiro, O. M.; Phytochemistry 1981, $20,543$.

115. Bruneton, J.; Pharmacognosy, Phytochemistry, Medicinal Plants, Intercept Ltd.: London, 1999.

116. Amaral, A. C. F.; Barnes, R. A.; Planta Med. 1997, 63, 485.

117. Stuart, K. L.; Graham, L.; Phytochemistry 1973, 12, 1973.

118. Araujo-Junior, V. T.; da Silva, M. S.; da Cunha, E. V. L.; Agra, M. D.; da Silva, R. N.; Barbosa, J. M.; Braz-Filho, R.; Pharm. Biol. 2004, 42, 62 .

119. Suárez, A. I.; Suleyma, B.; Delle Monache, F.; Compagnone, R. S.; Arvelo, F.; Nat. Prod. Res., 2004, 18, 421.

120. Araujo-Junior, V. T.; da Silva, M. S.; da Cunha, E. V. L.; Agra, M. D.; Athayde-Filho, P. F.; Vieira, I. J. C.; Braz-Filho, R.; Barbosa-Filho, J. M.; J. Braz. Chem. Soc. 2005, 16, 553.

121. Pieters, L.; De Bruyne, T.; Van Poel, B.; Vingerhoets, R.; Totté, J.; Van Den Benghe, D.; Phytomedicine 1995, 2, 17.

122. Gurgel, L. A.; Silva, R. M.; Santos, F. A.; Martins, D. T.; Mattos, P. O.; Rao, V. S.; Phytother. Res. 2001, 15, 319.

123. Wyde, P. R.; Ambrose, M. W.; Meyerson, L. R.; Gilbert B. E.; Antiviral Res. 1993, 20, 145.

124. Ubillas, R.; Phytomedicine 1994, 1, 77.

125. Abo, K. A.; Ogunleye, V. O.; Ashidi, J. S.; Phytother. Res. 1999 , 13, 494.

126. Kostova, I.; Iossifova, T.; Rostan, J.; Vogler, B.; Kraus, W.; Navas, H.; Pharm. Pharmacol. Lett. 1999, 9, 34.

127. Dalbo, S.; Jungensen, S.; Horst, H.; Ruzza, A. A.; Soethe, D. N.; Santos, A. R. S.; Pizzolati, M. G.; Ribeiro-do-Valle, R. M.; J. Pharm. Pharmacol. 2005, 57, 765.

128. González-Vázquez, R.; Diaz, B. K.; Aguilar, M. I.; Diego, N.; Lotina-Hennsen, B.; J. Agric. Food Chem. 2006, 54, 1217.

129. Markham, K.R.; Techniques of Flavonoid Identification, Academic Press: London, 1982.

130. Athikomkulchai, S.; Prawat, H.; Thasana, N.; Ruangrungsi, N.; Ruchirawat, S.; Chem. Pharm. Bull. 2006, 54, 262.

131. Pieters, L.; De Bruyne, T.; Claeys, M.; Vlietinck, A.; Calomme, M.; Berghe, D. V.; J. Nat. Prod. 1993, 56, 899.

132. Puebla, P.; Correa, S. X.; Guerrero, R.; Feliciano, A. S.; Biochem. Syst. Ecol. 2005, 33, 849.

133. Abe, I.; Takahashi, Y.; Morita, H.; Noguchi, H.; Eur. J. Biochem. 2001, 268, 3354.

134. Pereira, A. S.; Amaral, A. C. F.; Barnes, R. A.; Cardoso, F. R.; Aquino Neto, F. R.; Phytochem. Anal. 1999, 10, 254.

135. Mukherjee, R.; Axt, E. M.; Phytochemistry 1984, 23, 2682.

136. Barbosa, P. R.; Fascio, M.; Martins, D.; Roque, N. F.; Arkivoc 2004, 6, 95.

137. Milo, B.; Risco, E.; Vila, R.; Iglesias, J.; Canigueral, S.; C.; J. Nat. Prod. 2002, 65, 1143.

138. Barry, P.E.; Hipp, A.L.; Wurdack, K.J.; Van Ee, B.; Riina, R.; Am. J. Bot. 2005, 92, 1520.

139. Gershenzon, J.; J. Chem. Ecol. 1994, 20, 1281.
140. Farias, R. A. F.; Rao, V. S. N.; Viana, G. S. B.; Silveira, E. R.; Maciel, M. A. M.; Pinto, A. C.; Planta Med. 1997, 66, 558.

141. Appendino, G.; Borrelli, F.; Capasso, R.; Campagnuolo, C.; Fattorusso, E.; Petrucci, F.; Taglialatela-Scafati, O.; J. Agric. Food Chem. 2003, 51, 6970.

142. Chen, Z-P.; Cai, Y.; Phillipson, J. D.; Planta Med. 1994, 60, 541. 143. Jones, K.; J. Altern. Complem. Med. 2003, 9, 877.

144. Hiruma-Lima, C. A.; Gracioso, J. S.; Rodriguez, J. A.; Haun, M.; Nunes, D. S.; Souza-Brito, A. R. M.; J. Ethnopharmacol. 2000, 69, 229.

145. Hiruma-Lima, C. A.; Gracioso, J. S.; Bighetti, E. J.; GrassiKassisse, D. M.; Nunes, D. S.; Souza-Brito, A. R. M.; Phytomedicine 2002, 9, 523.

146. Fischer, H.; Machen, T. E.; Widdicombe, J. H.; Carlson, T. J. S.; King, S. R.; Chow, J. W. S.; Illek, B.; J. Ethnopharmacol. 2004, 93, 351.

147. Desmarchelier, C.; Witting Schaus, F.; Coussio, J.; Cicca, G.; J. Ethnopharmacol. 1997, 58, 103.

148. Gurgel, L. A.; Sidrim, J. J. C.; Martins, D. T.; Cechinel, V.; Rao, V. S.; J. Ethnopharmacol. 2005, 97, 409.

149. Prozesky, E. A.; Meyer, J. J. M.; Louw, A. I.; J. Ethnopharmacol. 2001, 76, 239.

150. Weniger, B.; Lagnika, L.; Vonthron-Sénécheau, C.; Adjobimey, T.; Gbenou, J.; Moudachirou, M.; Brum, R.; Anton, R.; Sanni, A.; J. Ethnopharmacol. 2004, 90, 279.

151. Rossi, D.; Bruni, R.; Bianchi, N.; Chiarabelli, C.; Gambari, R.; Medici, A.; Lista, A.; Paganetto, G.; Phytomedicine 2003, 10, 139.

152. Lopes, M. I. L. E.; Saffi, J.; Echeverrigaray, S.; Henriques, J. A. N.; Salvador, M.; J Ethnopharmacol. 2004, 95, 437.

153. Santos, F. V.; Mesquita, S. F. P.; Faria, M. J. S. S.; Poersh, A.; Maciel, M. A. M.; Pinto, A. C.; Morimoto, H. K.; Colus, I. M. S.; Genet. Mol. Biol. 2006, 29, 159.

154. Tieppo, M.; Porawski, M.; Salvador, M.; Moreira, A. J.; Collado, P. S.; Gonzalez-Gallego, J.; Marroni, N. P.; Biol. Pharm. Bull. 2006, 29, 161.

155. Magalhães, P. J. C.; Lahlou, S.; Vasconelos Dos Santos, M. A.; Pradines, T. L.; Leal-Cardoso, J. H.; Planta Med. 2003, 69, 874.

156. Lahlou, S.; Leal-Cardoso, J. H.; Magalhães, P. J. C.; Coelhode-Souza, A. N.; Pinto-Duarte, G.; Planta Med. 1999, 65, 553.

157. Guerrero, M. F.; Puebla, P.; Carrón, R.; Martin, M. L.; Arteaga, L.; Román, L. S.; J. Ethnopharmacol. 2002, 80, 37.

158. Abdon, A. P. V.; Leal-Cardoso, J. H.; Coelho-de-Souza, A. N.; Morais, S. M.; Santos, C. F.; Braz. J. Med. Biol. Res. 2002, 35, 1215.

159. Suárez, A. I.; Blanco, Z.; Compagnone, R. S.; Salazar-Bookaman, M. M.; Zapata, V.; Alvarado, C.; J. Ethnopharmacol. 2006, 105, 99.

160. Santos, F. A.; Jeferson, F. A.; Santos, C. C.; Silveira, E. R.; Rao, V. S. N.; Life Sci. 2005, 77, 2953. 
161. Suárez, A. I.; Compagnone, R. S.; Salazar-Bookaman, M. M.; Tillet, S.; Delle Monache, F.; Di Giulio, C.; Bruges, G.; J. Ethnopharmacol. 2003, 88, 11.

162. Lazarini, C. A.; Uema, A. H.; Brandão, G. M. S.; Guimarães, A. P. C.; Bernardi, M. M.; Phytomedicine 2000, 7, 477.

163. Maciel, M. A. M.; Pinto, A. C.; Veiga Jr., V. F.; Grynberg, N. F.; Echevarria, A.; Quim. Nova, 2002, 25, 429.

164. Silva, R. M.; Santos, F. A.; Rao, V. S. N.; Maciel, M. A. M.; Pinto, A. C.; J. Pharm. Pharmacol. 2001, 53, 535.

165. Silva, R. M.; Santos, F. A..; Maciel, M. A. M.; Pinto, A. C.; Rao, V. S.; Planta Med. 2001, 67, 763.

166. Tomei, D. L.; Noyes, I.; Blocker, D.; Holliday, J.; Glaser, R.; Nature 1987, 329, 73.

167. Singer, C.; Underwood, E. A.; A Short History of Medicine, Oxford University Press: New York, 1962, p. 674.

168. Van Duuren, B. L.; Orris, L., Arroyo, E.; Nature 1963, 200, 1115. 169. Arroyo, E. R.; Holcomb, J.; J. Med. Chem. 1965, 8, 672.

170. Hecker, E.; Bartsch, H.; Bresch, H.; Gshwendt, M.; Härle, E.; Kreibich, G.; Kubinyl, H.; Schairer, H. U.; Szczepanski, Ch. V.; Thielmann, H. W.; Tetrahedron Lett. 1967, 33, 3165.

171. Castagna, M.; Takai, Y.; Kaibuchi, K.; Sano, K.; Kikkawa, U.; Nishizuka, Y.; J. Biol. Chem. 1982, 257, 7847.

172. Nishizuka, Y.; Science 1992, 258, 607.

173. Aitken, A. In Naturally Occurring Phorbol Esters; Evans, E. J., ed.; CRC Press: Boca Raton, 1986, p. 271.

174. Bertolini, T. M.; Giorgione, J.; Harvey, D. F.; Newton, A. C.; J. Org. Chem. 2003, 68, 5028.

175. Abdel-Hafez, A. A. M.; Nakamura, N.; Hattori, M.; Chem. Pharm. Bull. 2002, 50, 160.

176. Melo, P. S.; Justo, G. Z.; Durán, N.; Haun, M.; Eur. J. Pharmacol. 2004, 487, 47.

177. Anazetti, M. C.; Melo, P. S.; Durán, N.; Haun, M.; Toxicology 2003, 188, 261.

178. Anazetti, M. C.; Melo, P. S.; Durán, N.; Haun, M.; Toxicology 2004, 203, 123.

179. Agner, A. R.; Maciel, M. A. M.; Pinto, A. C.; Pamplona, S. G. S. R.; Colus, I. M. S.; Teratogenesis Carcinog. Mutagen. 1999, 19, 377.

180. Agner, A. R.; Maciel, M. A. M.; Pinto, A. C.; Colus, I. M. S.; Planta Med. 2001, 67, 815.

181. Correa, D. H. A.; Melo, P. S.; de Carvalho, C. A. A.; de Azevedo, M. B. M.; Durán, N.; Haun, M.; Eur. J. Pharmacol. 2005, 510, 17.

182. Block, S.; Gerkens, P.; Peulen, O.; Jolois, O.; Mingeot-Leclercq, M. P.; De Pauw-Gillet, M. C.; Quetin-Leclerq, J.; Anticancer Res. 2005, 25, 363.

183. Cragg, G. M.; Newman, D. J.; Ann. Appl. Biol. 2003, 143, 127.

184. Kupchan, S. M.; Uchida, I.; Branfman, A. R.; Dailey, R. G.; Fel, B. Y.;.Science 1976, 191, 571.

185. Kawai, K.; Tsuno, N. H.; Kitayama, J.; Okaji, Y.; Yazawa, K.; Asakage, M.; Yamashita, H.; Watanabe, T.; Takahashi, K.; Nagawa, H.; Anticancer Drugs 2005, 16, 401.
186. Chainy, G. B. N.; Manna, S. K.; Chaturvedi, M. M.; Aggarwal, B. B.; Oncogene 2000, 19, 2943.

187. Matsumoto, Y.; Hamashima, H.; Masuda, K.; Shiojima, K.; Sasatsu, M.; Arai, T.; Microbios 1998, 96, 149.

188. Inoue, Y.; Shiraishi, A.; Hada, T.; Hirose, K.; Hamashima, H.; Shimada, J.; Fems Microbiol. Lett. 2004, 237, 325.

189. de Bruyne, T.; Pieters, L.; Deelstra, H.; Vlietinck, A.; Biochem. Syst. Ecol. 1999, 27, 445.

190. Wyde, P. R.; Meyerson, L. R.; Gilbert B. E.; Drug Develop. Res. 1993, 28, 467.

191. Barnard, D. L.; Smee, D. F.; Huffman, J. H.; Meyerson, L. R.; Sidwell, R. W.; Chemotherapy 1993, 39, 203.

192. Orozco-Topete, R.; Sierra-Madero, J.; Cano Dominguez, C.; Kershenovich, J.; Ortiz Pedroza, G.; Vazquez Valls, E.; Garcia Cosio, C.; Soria Córdoba, A.; Armendariz, A. M.; Teran Toledo, X.; Romo Garcia, J.; Fernandez, H.; Rozhon, E. J.; Antiviral Res. 1997, 35, 91.

193. Nakamura, N.; Yakugaku Zasshi-J. Pharm. Soc. Japan 2004, $124,519$.

194. Masuda, T.; Harada, S.; Virology 1993, 192, 696.

195. Souza-Brito, A. R. M.; Rodríguez, J. A.; Hiruma-Lima, C. A.; Haun, M.; Nunes, D. S.; Planta Med. 1998, 64, 126.

196. Hiruma-Lima, C. A.; Spadari-Bratfisch, R. C.; Kassisse, D. M.; Souza-Brito, A. R. M.; Planta Med. 1999, 65, 325.

197. Hiruma-Lima, C. A.; Toma, W.; Gracioso, J. S.; Almeida, A. B. A.; Batista, L. M.; Magri, L.; Bensuaski de Paula, A. C.; Soares, F. R.; Nunes, D. S.; Souza-Brito, A. R. M.; Biol. Pharm. Bull. 2002, 25, 452.

198. Rodriguez, J.A.; Hiruma-Lima, C.A.; Souza-Brito, A. R. M., Hum. Exp. Toxicol. 2004, 23, 455.

199. Almeida, A. B. A..; Melo, P. S.; Hiruma-Lima, C. A.; Gracioso, J. S.; Carli, 1.; Nunes, D. S.; Haun, M.; Souza-Brito, A. R. M.; Eur. J. Pharmacol. 2003, 472, 205.

200. Melo, P. S.; Durán, N.; Hiruma-Lima, C. A.; Souza-Brito, A. R. M.; Haun, M.; J. Ethnopharmacol. 2003, 87, 169.

201. Ushiyama, S.; Matsuda, K.; Asai, F.; Yamazaki, M.; Biochem. Pharmacol. 1987, 36, 369.

202. Takagi, A.; Koga, W.; Aiba, Y.; Kabir, A. M.; Watanabe, S.; Ohta-Tada, U.; Osaki, T.; Kamiya, S.; Miwa, T.; J. Gastroenterol. Hepatol. 2000, 15, 374.

203. Koga, T.; Inoue, H.; Ishii, C.; Okazaki, Y.; Domon, H.; Utsui, Y.; J. Antimicrob. Chemother. 2002, 50, 133.

204. Magalhães, P. J. C.; Lahlou, S.; Leal-Cardoso, J. H.; Fundam. Clin. Pharmacol. 2004, 18, 539.

205. Albuquerque, A. A. C.; Sorenson, A. L.; Leal-Cardoso, J. H.; J. Ethnopharmacol. 1995, 49, 41.

206. Di Cesare, D.; DuPont, H. L.; Mathewson, J. J.; Ashley, D.; Martinez-Sandoval, F.; Pennington, J. E.; Porter, S. B.; Am. J. Gastroenterol. 2002, 97, 2585.

207. Adam, G.; Ousingsawat, J.; Schreiber, R.; Kunzelmann, K.; Pflugers Arch. 2005, 449, 470. 
208. Holodniy, M.; Koch, J.; Mistal, M.; Am. J. Gastroenterol. 1999, 94, 3267.

209. Bighetti, E. J. B.; Hiruma-Lima, C. A.; Gracioso, J. S.; Brito, A. R. M.; J. Pharm. Pharmacol. 1999, 51, 1447.

210. Ichiara, Y.; Takeya, K.; Hitotsuyanagi, Y.; Morita, H.; Okuyama, S.; Suganuma, M.; Fujiki, H.; Motidome, M.; Itokawa, H.; Planta Med. 1992, 58, 549.

211. Carvalho, J. C. T.; Silva, M. F. C.; Maciel, M. A. M.; Pinto, A. C.; Nunes D. S.; Mendes Lima, R.; Bastos, J. K.; Sarti, S. J.; Planta Med. 1996, 62, 402.

212. Silva, R. M.; Oliveira, F. A.; Cunha, K. M. A.; Maia, J. L.; Maciel, M. A. M.; Pinto, A. C.; Nascimento, N. R. F.; Santos, F. A.; Rao, V. S. N.; Vasc. Pharmacol. 2005, 43, 11.
213. Norte, M. C. B.; Cosentino, R. M.; Lazarini, C. A.; Phytomedicine 2005, 12, 294.

214. Costa, A. M. L.; Silva, J. C. R.; Campos, A. R.; Rao, V. S. N.; Maciel, M. A. M.; Pinto, A. C.; Phytother. Res. 1999, 13, 689. 215. Smitt, O.; Hogberg, H-E.; Tetrahedron 2002, 58, 7691.

216. Fairnsworth, N. R. In Biodiversity; Wilson, E. O.; Peter, F. M., eds., National Academy Press: Washington D.C., 1988, p. 83.

217. Rudall, P.; Ann. Mo. Bot. Gard.1994, 81, 270.

218. Fahn, A.; New Phytol. 1988, 108, 229.

Received: August 9, 2006

Web Release Date: January 26, 2007

FAPESP helped in meeting the publication costs of this article. 